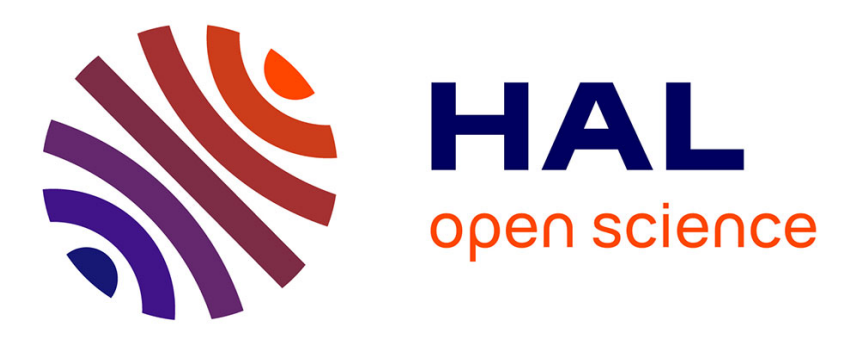

\title{
Kinematics of the Marmara Region: a fusion of continuum and block models
}

\author{
Volkan Özbey, Mehmet Sinan Özeren, Pierre Henry, Elliot Klein, Gerald \\ Galgana, Hayrullah Karabulut, Dietrich Lange, Robert Mccaffrey
}

\section{To cite this version:}

Volkan Özbey, Mehmet Sinan Özeren, Pierre Henry, Elliot Klein, Gerald Galgana, et al.. Kinematics of the Marmara Region: a fusion of continuum and block models. Mediterranean Geoscience Reviews, 2021, 10.1007/s42990-021-00051-y · hal-03173295

\section{HAL Id: hal-03173295 \\ https://hal.science/hal-03173295}

Submitted on 18 Mar 2021

HAL is a multi-disciplinary open access archive for the deposit and dissemination of scientific research documents, whether they are published or not. The documents may come from teaching and research institutions in France or abroad, or from public or private research centers.
L'archive ouverte pluridisciplinaire HAL, est destinée au dépôt et à la diffusion de documents scientifiques de niveau recherche, publiés ou non, émanant des établissements d'enseignement et de recherche français ou étrangers, des laboratoires publics ou privés. 


\title{
Kinematics of the Marmara Region: A Fusion of Continuum and Block Models
}

\author{
Volkan Özbey $^{1}$. Mehmet Sinan Özeren ${ }^{2}$. \\ Pierre Henry $^{3}$. Elliot Klein ${ }^{4}$. Gerald \\ Galgana $^{5}$. Hayrullah Karabulut ${ }^{6}$. Dietrich \\ Lange $^{7} \cdot$ Robert McCaffrey $^{8}$
}

Received: date / Accepted: date

\begin{abstract}
The Sea of Marmara has been the focus of numerous marine geophysical studies during the last couple of decades. Determination of the interseismic slip distribution along the Main Marmara Fault (MMF) has observational difficulties due to the fact that the fault is under the sea. In addition to the onshore geodetic studies, two underwater geodetic studies were carried out recently and brought new clues about locked/creeping status of two different fault segments. In this study, we investigate the interseismic deformation of the Marmara region from a kinematic perspective using both block and continuum kinematic models. Block model inversion yields relative motion along the block boundaries as well as the distribution of slip deficit on the faults bounding the blocks. Calculated long term slip rates are 19-20 mm/yr for the MMF and 3-4 mm/yr for the Southern branch of the North Anatolian Fault (SNAF). In order to determine the sensitivity of the slip deficit solution to arbitrary spatial discretizations, we perform a series of checkerboard tests and optimize node distribution on the MMF accordingly. We also explore the sensitivity of inversion results on the MMF to assumptions regarding SNAF long term slip and interseismic locking. This study shows that the underwater geodetic data can be combined with the GPS data in a joint inversion, bringing a better constrained slip deficit distribution on the MMF. MMF has aseismic creep in the west of the Marmara Sea, with creep rates approaching long term slip rates in the Central Basin. On the other hand, the fault appears locked from $\sim 28.2^{\circ} \mathrm{E}$ eastward. In the best fitting model, the Istanbul-Silıvrıfault segment is locked down

\footnotetext{
Volkan Özbey

${ }^{1}$ Istanbul Technical University, Department of Geomatics Engineering, Maslak, Istanbul, Turkey

2 Istanbul Technical University, Eurasia Institute of Earth Sciences, Maslak, Istanbul, Turkey

3 Aix Marseille Univ, CNRS, IRD, INRA, Coll France, CEREGE, Aix-en-Provence, France

4 FM Global Research, Research Division, Norwood, MA, United States

5 Framingham State University, Department of Physics and Earth Science, Framingham, United States

6 Bogazici University, Kandilli Observatory and Earthquake Research Institute, Department of Geophysics, Istanbul, Turkey

7 GEOMAR Helmholtz Centre for Ocean Research Kiel, Kiel, Germany

8 Portland State University, Department of Geology, Portland, United States
}

E-mail: ozbeyv@itu.edu.tr
\end{abstract}


to $\sim 10 \mathrm{~km}$. The existence of a hazardous seismic gap in the Sea of Marmara, potentially yielding a magnitude 7.5 earthquake, is thus confirmed. The continuum approach is used to calculate strain rate fields from GPS data alone, from the output (slip rates and block average strain rates) of the best-fitting block model, and from the GPS residuals of this model. Our continuum models show that most of the accumulated strain in the Marmara region is indeed focused around the MMF, but also that strain distributed within the blocks cannot be neglected. On the other hand, the SNAF system differs from the MMF in that it appears as a $50 \mathrm{~km}$ wide zone of deformation with a patchy distribution of strain reflecting the activity of individual faults.

Keywords Main Marmara Fault - Interseismic deformation - Block Model • Continuum Kinematic model

\section{Introduction}

The Marmara region, and in particular, the Sea of Marmara has been an intense focus of several tectonic, geodetic and marine geophysical studies in the last two decades. The main precursor of these studies was the $M_{w} 7.41999$ Izmit earthquake which was (together with the $M_{w} 7.2$ Düzce earthquake that occurred on the same year) the last big seismic event in the sequence of westward propagating earthquakes on the North Anatolian Fault during the $20^{\text {th }}$ century (e.g. Bouchon et al., 2011). The Izmit 1999 earthquake ruptured the North Anatolian Fault onshore, directly east of the Gulf of Izmit, which forms the easternmost portion of the Sea of Marmara (Çakir et al., 2003; Gasperini et al., 2011). The North-Anatolian Fault (NAF) in the Sea of Marmara remained as unbroken fault segment which ruptured last in 1766. This initiated a lively scientific debate on the state of interseismic slip in the Marmara fault system, given the need to produce realistic earthquake scenarios for the city of Istanbul and surrounding areas. A certain level of consensus has been reached on the geometry of the Main Marmara Fault (hereafter, MMF; the continuation of the NAF into the Sea of Marmara). However, the kinematics of the system has been very difficult to study due to lack of geodetic observations close to this underwater fault. An additional difficulty is to quantify the partitioning between the MMF and the Southern strand (Armijo et al., 2002; Flerit et al., 2003; Şengör et al., 2005) connecting the NAF to the North Skyros Basin in the Aegean domain (Yaltırak et al., 2012). The central segment of the MMF hasn't broken since the 1766 Istanbul earthquake. Therefore, one of the most important practical questions about the future earthquake scenarios focused on the accumulated slip and thus on the creeping versus locked state of the MMF (Ergintav et al., 2014; Schmittbuhl et al., 2016; Lange et al., 2019).

Meade (2002) derived a block kinematic model of the Sea of Marmara to study the earthquake potential of the fault system. Hergert et al. (2011) and Hergert and Heidbach (2011) performed a dynamic approach to the problem, taking into account the horizontal variations of gravitational potential energies and compared their results with GPS observations.

Ergintav et al. (2014) constructed a simple model of a single fault with segments and used a one-dimensional approach to invert for the locking depth along the fault for different segments using onshore stations. The main purpose of the 
work by Ergintav et al. (2014) was to determine whether or not the central segment of the MMF (the part of the MMF lying approximately between $28^{\circ} \mathrm{E}$ and $29^{\circ} \mathrm{E}$ ) is locked. This segment is characterized by sparse seismicity and the last major rupture on it was the $M_{w} 7.21766$ earthquake (Hubert-Ferrari et al., 2002; Parsons, 2004; Pondard et al., 2007). Since the onshore GPS stations did not detect any significant elastic locking signal, they concluded that this part of the fault might not be locked. However, a recent underwater geodetic study, measuring baseline changes on the seafloor across the MMF, found that the segment is locked and accumulating elastic strain (Sakic et al., 2016; Lange et al., 2019). These studies suggest that the segment is locked at least down to $3 \mathrm{~km}$ or possibly deeper into the crystalline basement. Furthermore, another underwater geodetic study by Yamamoto et al. (2019), to the west of this segment, on the Western High, detected considerable creep $(10.7 \pm 4.7 \mathrm{~mm} / \mathrm{yr})$. At the eastern end of the Sea of Marmara, newly available InSAR data (Aslan et al., 2019) indicates that the creep that followed the 1999 Izmit earthquake decayed but is still present (around $8 \mathrm{~mm} / \mathrm{yr}$ ). These, combined with the conclusion of Ergintav et al. (2014) that the Prince Islands segment to the east of the central segment is also locked suggests an interseismic fault regime that is spatially variable.

Our aim in this manuscript is to use both a block model and a continuum model to incorporate all GPS data that became available during the last decade, including the underwater geodetic data, to better constrain the slip state (the degree at which the locking occurs during the interseismic period) of the Marmara fault system. The newly available underwater geodetic data gives us additional kinematic constraints within the Sea of Marmara in addition to the far-field constraints by the GPS data onshore.

In the block model, we perform a set of synthetic checkerboard tests to determine the resolution of the spatial distribution of the GPS observations in terms of their ability to determine the interseismic slip distribution for the particular fault geometry. Since the block interactions may be significant, we also investigate the effect of assumptions on the slip state (in terms of a kinematic boundary condition) of the southern branch on the calculated slip state of the MMF. The final block model is then used as a kinematic constraint for our continuum kinematic model through a Kostrov summation (Beavan and Haines, 2001). We then compare our resulting Kostrov-based solution with the one which uses solely GPS data (i.e., without any fault constraint coming from the block model). This comparison enables us to determine the limitations of the block architecture, because the GPS only continuum solution possibly detects deformation features within the blocks which are not resolved in the block model and the resulting Kostrov model.

\section{GPS Data}

We use GPS velocities (a total of 217 observation points) and data from two direct acoustic path ranging experiments on the seafloor as kinematic constraints. The GPS velocities are taken from four studies (Reilinger et al., 2006; Aktuğ et al., 2013; Ergintav et al., 2014; Özdemir, 2016). Here it is important to note that there are some more recent GPS data in the region (for instance, the GPS data published together with the InSAR data in Aslan et al. (2019) but for the purpose of this study 
we use data that largely overlapped in time and therefore sampled roughly the same kinematic epoch.

Each of the above-mentioned, four GPS studies cover different number of GPS sites but the large number of sites are shared by all of them. Since each dataset has been processed by different groups and also considering that there are differences in the reference system used, we needed to express them in a unique frame of reference. Our strategy was to anchor all GPS velocities to the global reference frame defined by Reilinger et al. (2006). This is because Reilinger et al. (2006) includes the highest number of common stations. The method of anchoring that we utilized is based on an algorithm developed by (Herring et al., 2018). In simple terms, the algorithm has two stages. In the first stage, it accounts for the differences in the reference systems according to Eq. 1 and Eq. 2 below.

$$
\begin{gathered}
\Delta \vec{v}=\left[\begin{array}{c}
W_{x}^{(2)}-W_{x}^{(1)} \\
W_{y}^{(2)}-W_{y}^{(1)} \\
W_{z}^{(2)}-W_{z}^{(1)}
\end{array}\right] \times \overrightarrow{\mathbf{r}} \\
\vec{v}_{2}=\vec{v}_{1}+\Delta \vec{v}
\end{gathered}
$$

where $v_{1}$ and $v_{2}$ are the velocities of the station in the initial and final reference system, respectively. $\left[W_{x}^{(i)}, W_{y}^{(i)}, W_{z}^{(i)}\right]$ are the angular velocity vectors $(i=1,2)$ according to initial and final reference frame and $\overrightarrow{\mathbf{r}}$ is the Cartesian position vector of the station. Angular velocity values for various transformations mentioned above are taken from Altamimi et al. (2017), Table 1, Altamimi et al. (2012) Table 3 and Altamimi et al. (2002) Table 6. In the second stage, the algorithm uses the common stations between two sets of observations to obtain an optimal transformation matrix to anchor one dataset to the other. The algorithm is based on a least-squares inversion to solve for optimal transformation matrices for the subset of the entire dataset that includes common stations. The forward problem is given as:

$$
G T=l
$$

where $T$ is the transformation matrix that involves rotation, scaling and translation. $G$ is the partial derivatives with respect to transformation parameters in Earth Centered Earth Fixed (ECEF) coordinate system and $l$ is the velocity difference of the common stations between two solutions. The least-squares approximation for $l$ (we will show it as $\hat{l}$ ) is given as:

$$
T_{e n u}=\left(G_{e n u}^{T} W G_{e n u}\right)^{-1} G_{e n u}^{T} W \hat{l}_{e n u}
$$

where $T_{\text {enu }}$ is the transformation matrix and $G_{e n u}$ is the partial derivatives with respect to transformation parameters, $\mathrm{W}$ is the weight matrix (inverse of the average of two systems covariance matrix for common stations) and $\hat{l}_{e n u}$ is the velocity differences for common stations. "enu" indicates that the relevant matrix is at the local geocentric system. Once $T_{\text {enu }}$ has been approximated, both $G$ and $T$ are then expressed in the ECEF system to finally calculate velocities in final reference frame using Eq.5.

$$
\vec{v}_{s y s 2}=\vec{v}_{s y s 1}+G T
$$


Taking Reilinger et al. (2006) as the reference frame, we rotated the three remaining datasets to anchor them to this frame (Fig 1). The final combined GPS velocity field is given in Supplementary Material.

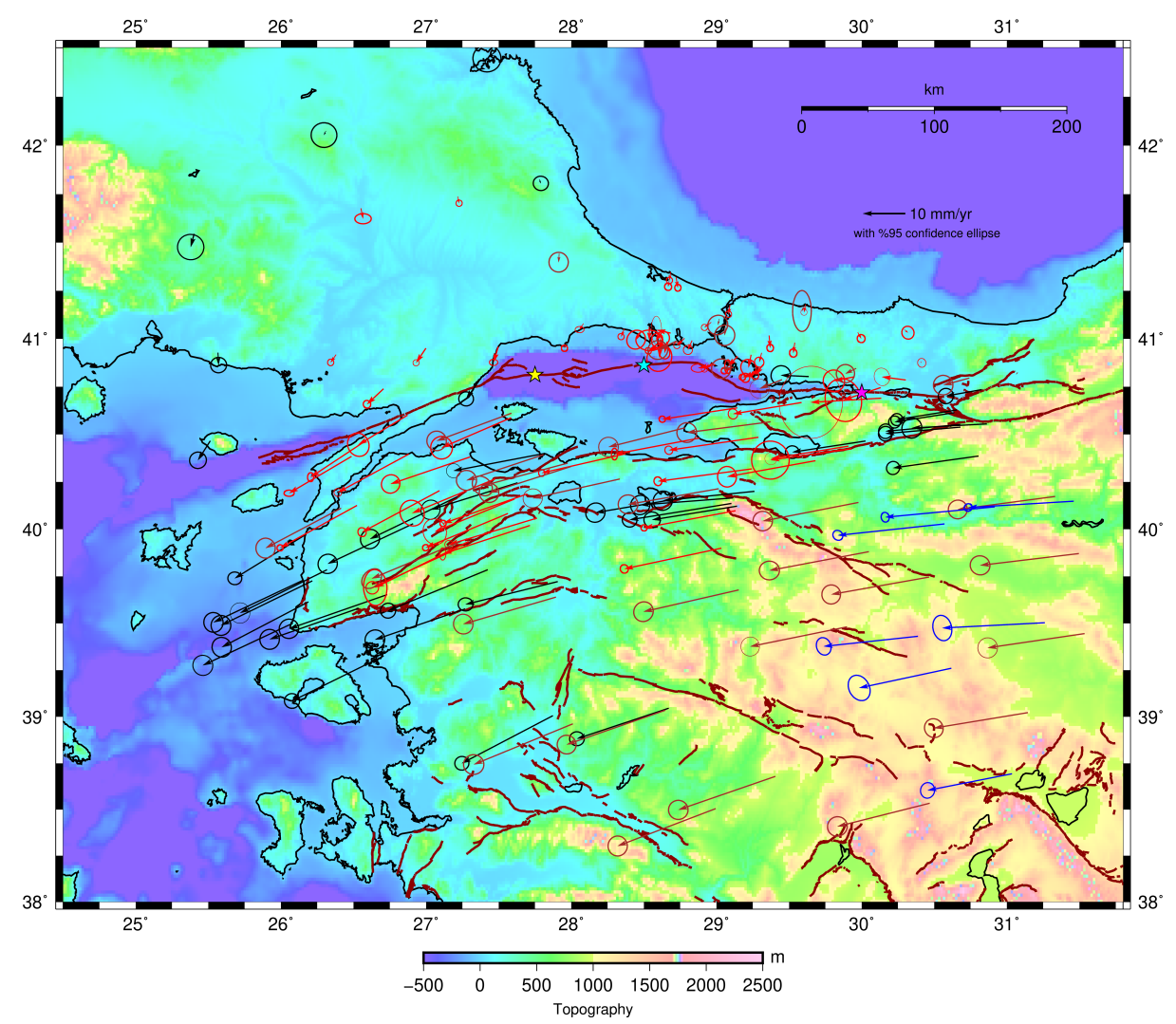

Fig. 1 GPS velocities, which coming from different studies, with respect to Eurasia and \%95 confidence ellipses after transformation black arrows belong to Reilinger et al. (2006), red ones are Ergintav et al. (2014), browns are coming from Özdemir (2016) and blue arrows are Aktuğ et al. (2013). The yellow star indicates the study area of Yamamoto et al. (2019), white star shows the location of the observed offshore geodetic observations by Lange et al. (2019) and the blue star is the location where Aslan et al. (2019) observed shallow creep using InSAR and GPS observations on the eastern part of the Marmara. Black lines are the active faults around the study area taken from Emre et al. (2013) and Emre et al. (2018).

In Table 1, we summarize the different reference systems used in these four studies and the root mean square (RMS) misfits for each group of observations. 
Table 1 GPS velocity solutions that used in this study, their reference frame, number of common stations for each combination, unified reference frame after combination and Root Mean Square of the common stations velocity residuals

\begin{tabular}{ccccc}
\hline Study & $\begin{array}{c}\text { Reference } \\
\text { Frame }\end{array}$ & $\begin{array}{c}\text { Number of } \\
\text { Common } \\
\text { Stations }\end{array}$ & $\begin{array}{c}\text { Final } \\
\text { Reference } \\
\text { Frame }\end{array}$ & $\begin{array}{c}\text { RMS fit } \\
\text { of the } \\
\text { Transformation (mm/yr) }\end{array}$ \\
\hline Reilinger et al. (2006) & EURA_I00 & - & EURA_I14 & - \\
Aktuğ et al. (2013) & EURA_I00 & 23 & EURA_I14 & 0.41 \\
Ergintav et al. (2014) & EURA_I08 & 27 & EURA_I14 & 0.70 \\
Özdemir (2016) & ITRF96 & 24 & EURA_I14 & 0.52 \\
\hline
\end{tabular}

\section{Modeling}

In this section, we aim to explain two different kinematic model approaches and their results. Each approach has been divided into subsections. We firstly present to the block model inversion method, definition of the block geometry, assessment of long term fault rates, synthetic tests that have been carried out for locking distribution of the MMF, and inversion for locking distribution on both MMF and SNAF. The continuum model section contains the general explanation of the theory and the results we obtained using this method.

\subsection{Block Model}

\subsubsection{Equations and inversion algorithm}

The block model approach in this study is based on the algorithm given in McCaffrey (2002) and McCaffrey et al. (2007). The term block means a closed polygon that rotates, deforms elastically along its boundaries due to friction with the adjacent blocks, and also deforms by uniform strain rate. The algorithm produces one angular velocity, one uniform horizontal strain rate tensor for each block and the locking distributions for each fault plane that defines block boundaries. The velocity at any point then satisfies

$$
\begin{array}{r}
V_{k}(\mathbf{X})=\left[_{\mathrm{R}} \boldsymbol{\Omega}_{\mathrm{B}} \times \mathbf{X}\right]_{k}+\varepsilon_{k k} \Delta \mathbf{X}_{k}+\varepsilon_{k l} \Delta \mathbf{X}_{k l}+\varepsilon_{l l} \Delta \mathbf{X}_{l}+ \\
\sum_{j=1,2} \sum_{i=1, \mathrm{~N}}\left[V_{j} \phi_{i}\right] G_{j k}\left(\mathbf{X}, \mathbf{Q}_{i}\right)
\end{array}
$$

which defines the relationship of the velocities to the output parameters. In the Eq. $6, \mathrm{X}$ is the position of the surface observation point, $k$ is the Cartesian components of the velocity vector and $\Delta \mathbf{X}$ represents the offset from the center of the polygon which is used to calculate the uniform internal strain rate.

In order to estimate parameters for Eq. 6 linear (Lines and Treitel, 1984) and nonlinear (Press et al., 1989) inversion steps are applied iteratively. The solution for the parameters in the equation above is performed in two steps. During the first step, the angular velocity for each block and the uniform internal strain rate tensor $\left(\varepsilon_{k k}, \varepsilon_{k l}, \varepsilon_{l l}\right)$ are calculated without any elastic loading on the faults. The second step is related to the elastic deformation part of the problem and to solve this part, the 
unit response functions $\left(G_{j k}\left(\mathbf{X}, \mathbf{Q}_{i}\right)\right)$ are used. Velocities of the observation points $\left(V_{k}(\mathbf{X})\right)$ are solved using dislocation model for a uniform elastic half-space Okada $(1985,1992)$. In order to calculate these surface velocities a backslip approach is applied to the nodes ( $N$ is the total number of nodes in Eq. 6) which are defined on the fault plane. Backslip rate is calculated from the locking fraction $\left(\phi_{i}\right)$ inverted for each node. When $\phi_{i}$ is equal to zero, the blocks at each side of this node slide freely past each other at this particular point. Basically, the algorithm aims to minimize function given Eq. 7.

$$
X_{n}^{2}=\left[\sum_{i=1, \mathrm{~N}} \mathrm{r}_{\mathrm{i}}^{2} /\left(\mathrm{s}_{\mathrm{i}} \mathrm{F}\right)^{2}\right] /(n-k)
$$

where $r$ is the residual (observed minus calculated velocity), $s$ is the standard deviation, $F$ is the scaling factor, $n$ is the number of observations and $k$ is number of free parameters.

\subsubsection{Block geometry and block motion}

In this section we explain how constraints from geology have been used to define the geometry of the block boundaries and examine the compatibility of the block motions obtained with geological fault slip rates. As explained in the above section, the inversion algorithm yields parameters defining block motion and internal block deformation as well as the instantaneous backslip distribution on the faults bounding the blocks. In the iterative scheme, the block motions depend on the backslip parameters, but not strongly if a significant part of the velocity data were acquired at sufficiently large distances from the fault. The relative velocity of the blocks along their boundaries defines the long term velocity of the block boundary faults and may be compared with geological estimates of faults rates.

Figure 2 shows the block geometry that we used in the solutions. The geometry of the Anatolian block (Anat) was taken from Reilinger et al. (2006) and its southwestern boundary was cut out in order not to include the extension in the Aegean.

The geometry of the Northern Strand of the North Anatolian Fault is well known and as far as the MMF is concerned (Le Pichon et al., 2001), there is little difference between the published fault maps. The geometry of secondary faults and splays and assessment of their activity may vary between fault models (Armijo et al., 2002; Rangin et al., 2004; Şengör et al., 2014; Seeber et al., 2006), but these geometrical complexities cannot be taken into account in the simplified geometry of the block model.

The Southern Strand (we will refer to this branch as Southern strand of North Anatolian Fault (SNAF)) on the North Anatolian Fault runs from a segment of the North Anatolian Fault segment that ruptured in 1967, located southeastward of the 1999 rupture, and connects it to the Aegean extensional system (Armijo et al., 2002; Flerit et al., 2003; Şengör et al., 2005). This fault system, having less cumulative displacement than the Northern Strand - which comprises the MMF - is less evolved and does not feature a principal through-going fault. In fact, the Southern Strand comprises several branches (Emre et al., 2018)(Fig. 1). One branch, which may be designated as the Gemlik Branch, goes through Gemlik Bay and along the southern coast of the Sea Marmara to the Bandirma area (Okay and Aydemir, 2016), from where it may be followed onshore in a SW direction. Another system, composed of 


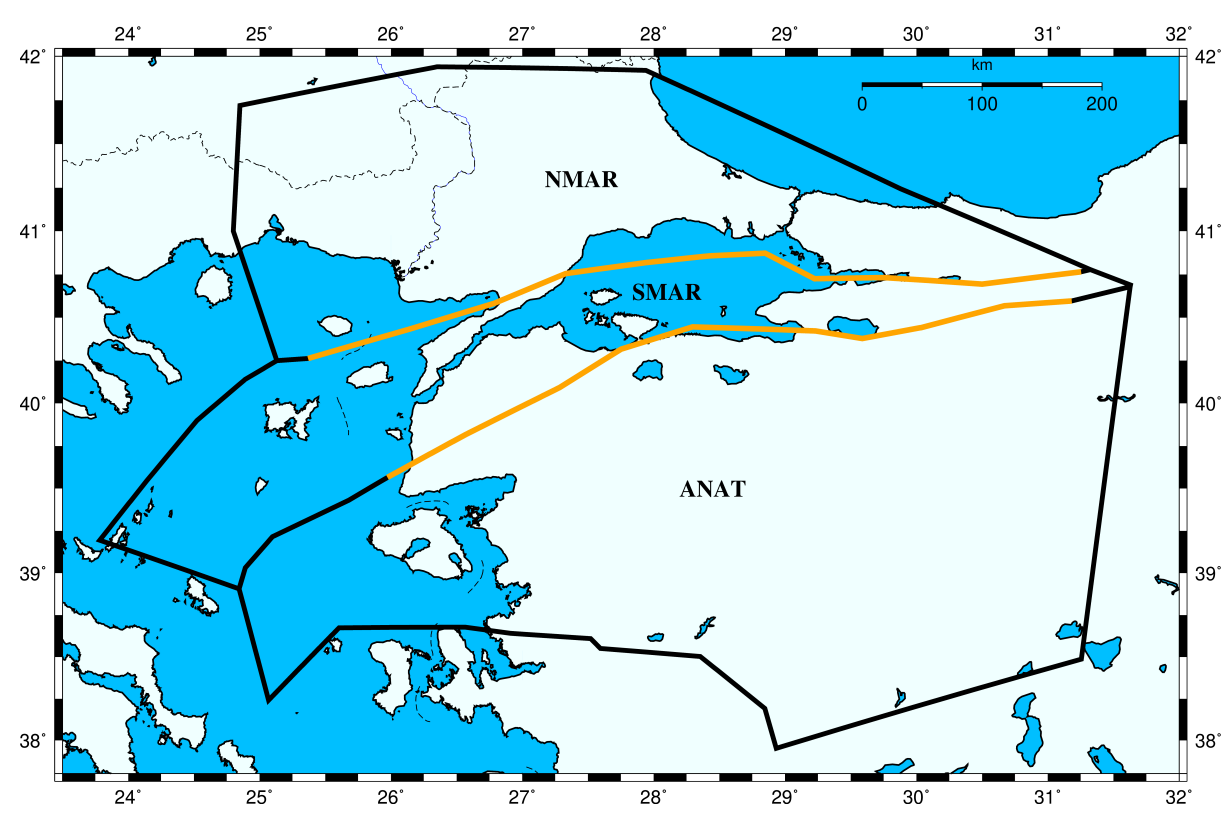

Fig. 2 The block geometry. The orange lines are the representation of the MMF and SNAF while the black lines are the other block boundaries which do not accumulate elastic strain. Abbreviations are: Northern Marmara (NMAR), Southern Marmara (SMAR), Anatolia (ANAT).

en-echelon faults, runs on land further south. Both systems meet at the SW end of the Biga peninsula and eventually connect to the North Skyros basin in the Aegean (Yaltırak et al., 2012; Sözbilir et al., 2017). It would not possible to define a block between these two branches, because this narrow zone is less than $30 \mathrm{~km}$ wide, and because the available GPS data would not constrain the motion of this block well enough to resolve the slip partitioning between its northern and southern boundaries. We retain the Gemlik Branch as a block boundary because its presence or absence in the model, and the parameters applied to it, should have a stronger influence on inversion results on the MMF. The geodetic stations located along the southern shore of the Sea of Marmara are likely influenced by the faults running along the coast.

Strike-slip rates on the MMF were estimated over various time scales. Interpretations of seismic stratigraphy yield average rates over the last 400,000 to 500,000 years, $18.5 \mathrm{~mm} / \mathrm{yr}$ (with a large formal uncertainty from 12.5 to $29 \mathrm{~mm} / \mathrm{yr}$ ) in Cinarcik Basin (Kurt et al., 2013) and $17.3 \pm 2.3 \mathrm{~mm} / \mathrm{yr}$ on the Western High (Grall, 2013). These rates are consistent with rates obtained from trenching studies and geomorphological studies on land (Zabc1, 2019). For instance, radiocarbon dating of offsets at Guzelkoy (around $27.3^{\circ} \mathrm{E}$ yield $17 \pm 5 \mathrm{~mm} / \mathrm{yr}$ over the last 1000 years. On the other hand, rates determined offshore from offset pre-Holocene morphologies tend to be lower (Polonia et al., 2004; Gasperini et al., 2011), about $10 \mathrm{~mm} / \mathrm{yr}$. Possible explanations for these lower rates are distributed deformation in soft sediment and partitioning on other fault branches within a flower structure. Furthermore, there are two published studies on the geologic slip rates for SNAF (Gasperini et al., 2011; Vardar et al., 2014). Both studies are based on the observations regard- 
ing the buried delta front in Gemlik Bay but differ on the offset measurement and age estimation. Gasperini et al. (2011) reported a $42 \mathrm{~m}$ offset for 11,000 years (corresponding to geologic slip rate of $4 \pm 0.4 \mathrm{~mm} / \mathrm{yr}$ ), while Vardar et al. (2014) find a $60 \mathrm{~m}$ offset for 30,000 years, roughly corresponding to $2 \mathrm{~mm} / \mathrm{yr}$.

Our geodetic inversion results are compatible with the geologically observed fault rates once uncertainties are taken into account but are on average higher, with slip rates ranging from $19.0 \mathrm{~mm} / \mathrm{yr}$ to $22.3 \mathrm{~mm} / \mathrm{yr}$ with a typical uncertainty of 0.6 $\mathrm{mm} / \mathrm{yr}$ on pure strike slip segments (Fig. 3). On the Prince Island segment, strikeslip rate is lower $(16.9 \pm 0.6 \mathrm{~mm} / \mathrm{yr})$ because of the obliquity and $10.8 \pm 1.6 \mathrm{~mm} / \mathrm{yr}$ of fault normal extension is inferred. In fact, this extension is partitioned on normal faults in Cinarcik Basin (Le Pichon et al., 2003) and on faults in Imrali Basin rooting on a detachment fault (Bécel et al., 2009; Le Pichon et al., 2016). Strike-slip rates obtained on the SNAF vary between $4.4 \pm 1.7 \mathrm{~mm} / \mathrm{yr}$ to $3.0 \pm 0.8 \mathrm{~mm} / \mathrm{yr}$ (see Fig. 3) and are thus consistent with slip rates obtained by Gasperini et al. (2011) in Gemlik Bay. These velocities of the block bounding faults are smaller than in the block model of Meade (2002), possibly because we allow for internal block strain. The middle SMAR block and the ANAT block are subject to minor distributed shearing and extension.

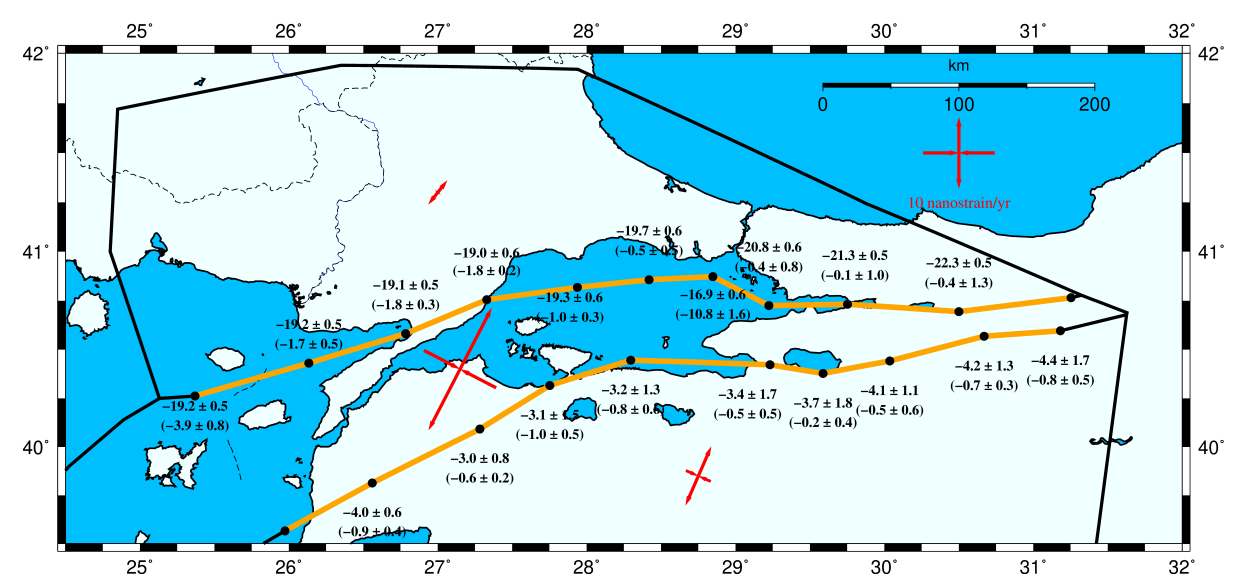

Fig. 3 Slip rates coming from the block model inversion both on the MMF and SNAF. Numbers in the parentheses are the fault-normal, (-) shows extension. No parentheses values are the strike-slip component. Negative means right lateral. Red arrows also show the block principal strain rates that coming from best-fitting block model inversion.

Because the block model projects the relative motion between the blocks on a single discontinuity, it is unsurprising that predicted fault rates remain higher than the observed ones. Indeed, Hergert and Heidbach (2010) evaluated the influence of secondary fault branches and continuum deformation on the slip rate on the main faults with a finite element model. According to that model, the rightlateral slip rates on the MMF is between $12.8 \mathrm{~mm} / \mathrm{yr}$ and $17.8 \mathrm{~mm} / \mathrm{yr}$, and ranges $1-4 \mathrm{~mm} / \mathrm{yr}$ on secondary faults within the Northern Strand of the North Anatolian Fault (NNAF) system. Fault slip rates are also found to vary along-strike. As in this study, the minimum strike-slip rate on the MMF is found on the Prince Island segment, largely because of its obliquity, and maximum slip rates in the Izmit Gulf. 
Hergert and Heidbach (2010) also infer approximately $3 \mathrm{~mm} / \mathrm{yr}$ slip rates along the SNAF.

We surmise that the block velocity obtained by inversion of GPS data account well for the tectonic rates, but because of the simplified geometry of the block boundaries, that only takes into account the main faults, the motion along the main faults is somewhat overestimated, but not more than $10-15 \%$. This could lead to slightly underestimated locking ratios.

\subsubsection{Synthetic Tests}

We performed a series of synthetic tests to assess the accuracy and stability of the inversion for the slip distribution on the MMF. To do so in the concept of the block model we have to define block motions relative to the reference frame. At this stage, we used the related Euler pole parameters that were estimated in Reilinger et al. (2006) Table 1. Here, we display the results from two tests. Tests targeted solely the accuracy and stability of the block model as a function of the spatial density of the GPS observations without any additional on-fault constraints. The parameters that are inverted for are the slip values on the nodes (the vertices of the quadrilateral fault patches). The tests have a checkerboard pattern on the same fault geometry with the identical distribution of the nodes that we utilized in our inversion using the real data. This two synthetic inversion tests are based on two forward elastic models that yield the displacement values at the geographic locations where we have the actual GPS observations (Okada, 1985, 1992). We perturb these values with the real errors associated with the GPS data, scaled to the synthetic values. Our checkerboard patterns are composed of an array of quadrilateral patches of the fault plane Fig. 4 where we imposed two different values of fault locking ratio ( $\phi$ in equation (4) in McCaffrey (2002)) in a checkerboard style $(\phi=0.1$ and $\phi=0.9)$.

In Fig. 5, we show a result with a higher resolution $(20 \times 5 \mathrm{~km}$ along strike and downdip, respectively) of slip patches that leads to an inversion instability. Checkerboard tests are particularly needed for the MMF because the previous studies (Ergintav et al., 2014; Schmittbuhl et al., 2016; Lange et al., 2019) indicate slip patterns that have significant spatial variability along the strike of the fault.

The synthetic tests lead to the conclusion that the slip patch resolution given in Fig. 4 seems optimal. Fig. 6 shows the slip inversion result of these two tests.

The inversions use the following differential relation to penalize non-smooth features of the slip distribution on the fault plane

$$
\text { Penalty }=\mathrm{A}_{1} \frac{\mathrm{dS}}{\mathrm{dx}}+\mathrm{A}_{2} \frac{\mathrm{dS}}{\mathrm{dw}}
$$

where $A_{1}$ and $A_{2}$ are the smoothing parameters that scale the penalties for smoothing in the along-strike and down-dip directions respectively and derivatives $d x$ and $d w$ are horizontal and downdip respectively.

As seen in these figures the inversion with lower resolution is particularly satisfactory for the shallower patches and acceptable also for the deeper patches. The statistical results of the inversion are shown in Table 2 . The section of the fault between $\sim 28.2^{\circ} \mathrm{E}$ and $\sim 28.9^{\circ} \mathrm{E}$, as shown in Fig. 6, really struggles to satisfactorily resolve the finer checkerboard test, to the extent that the estimated locking ratio shows some severe trade-offs among neighboring nodes, particularly in the central 


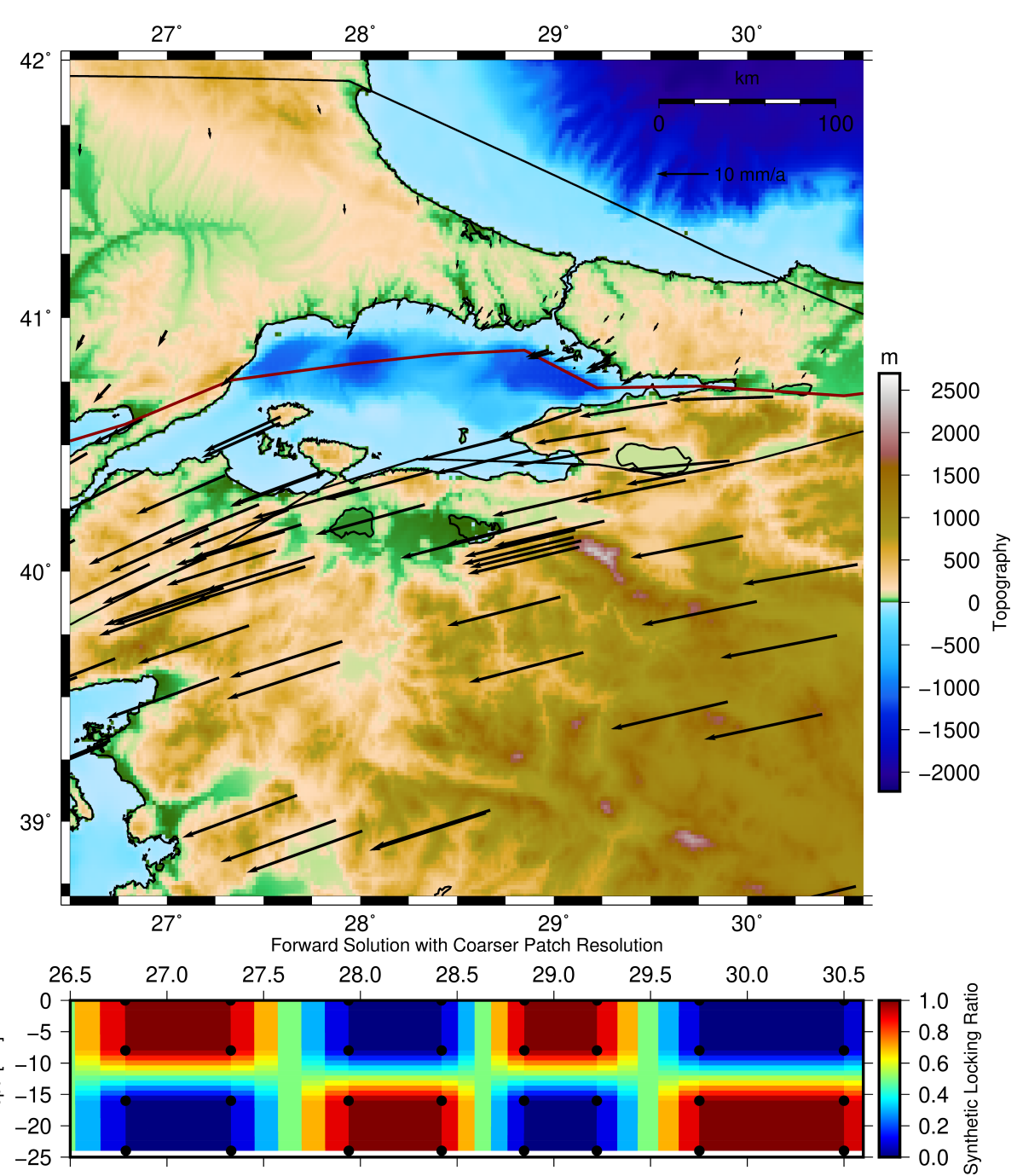

Fig. 4 Forward checkerboard solution carried out with lower fault patch resolution. In the map, black arrows represent displacements at points that correspond to the geographic locations of the GPS stations to be used in the real data inversion. Black lines show the block geometry and red line represents the MMF for this model. Cross-section profile shows the imposed locking ratio pattern of the synthetic test. Black dots are the node points on the fault plane.

Marmara region. Although the coarser checkerboard (Fig. 4) is reproduced satisfactorily, much of that reproduction is likely determined by the spacing of the checkerboard relative to the distance of the sites from the fault in that central Marmara region and the spacing between sites. The finer checkerboard nevertheless proves the point that, given the spacing of the available GPS data, that region remains poorly resolved unless one makes larger-scale assumptions about the consistency of the slip rates along strike, where data coverage is better anyway. 


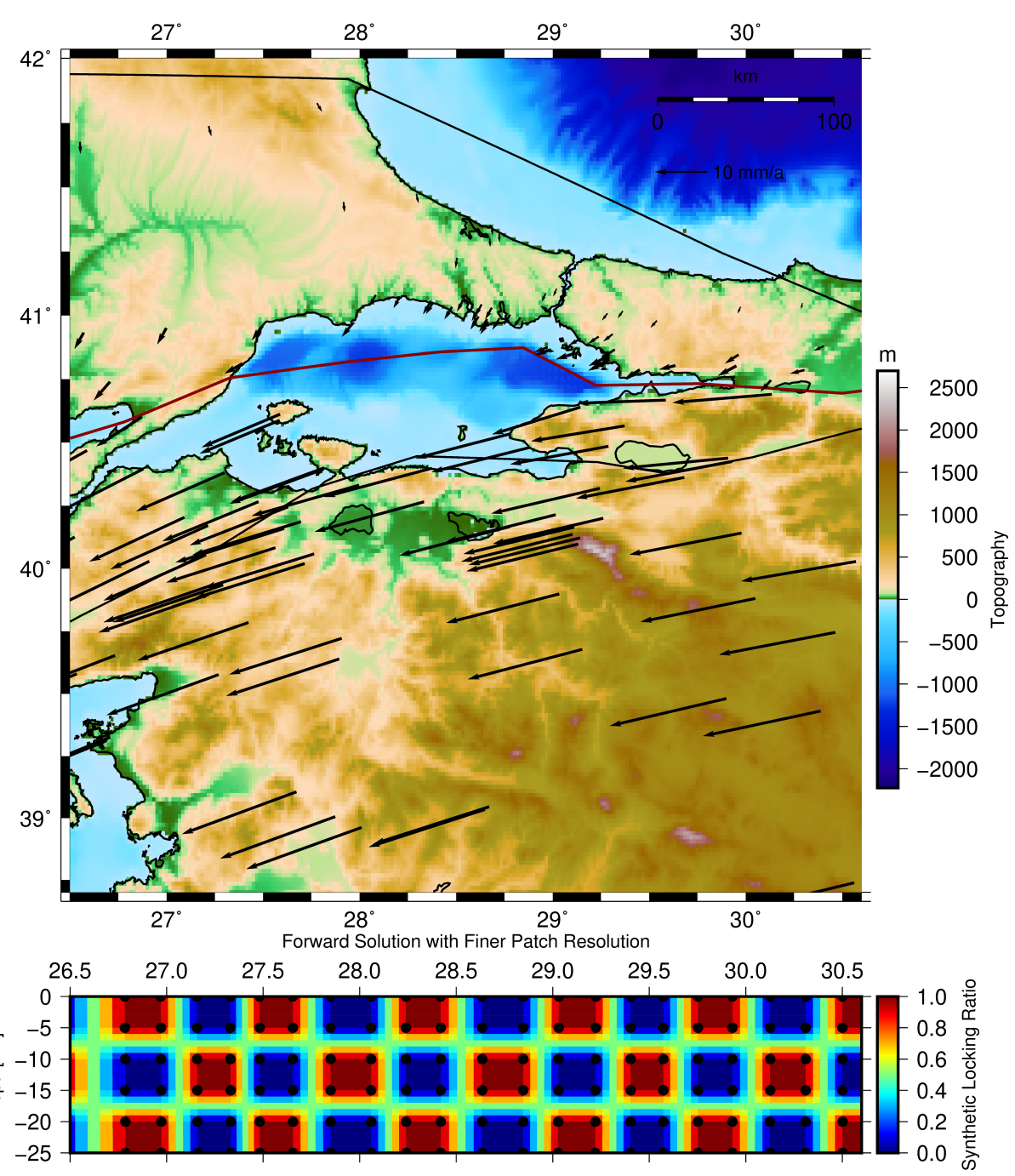

Fig. 5 Forward checkerboard solution carried out with finer fault patch resolution. This figure has same parameters with Fig. 4. In this forward model, higher resolution patches are defined

Table 2 Statistical summary of the optimal checkerboard test inversion. DOF is the abbreviation of the data Degrees of Freedom and determined using DOF $=(n-k)$, where $\mathrm{n}$ and $\mathrm{k}$ are defined in (Eq.7). Misfit is also calculated according to (Eq.7).

\begin{tabular}{cccc}
\hline Test Type & Number of Inverted Parameters & DOF & Misfit \\
\hline Inversion with $70^{*} 8 \mathrm{~km}$ patches & 33 & 420 & 1.21 \\
Inversion with $20^{*} 5 \mathrm{~km}$ patches & 66 & 387 & 5.58 \\
\hline
\end{tabular}



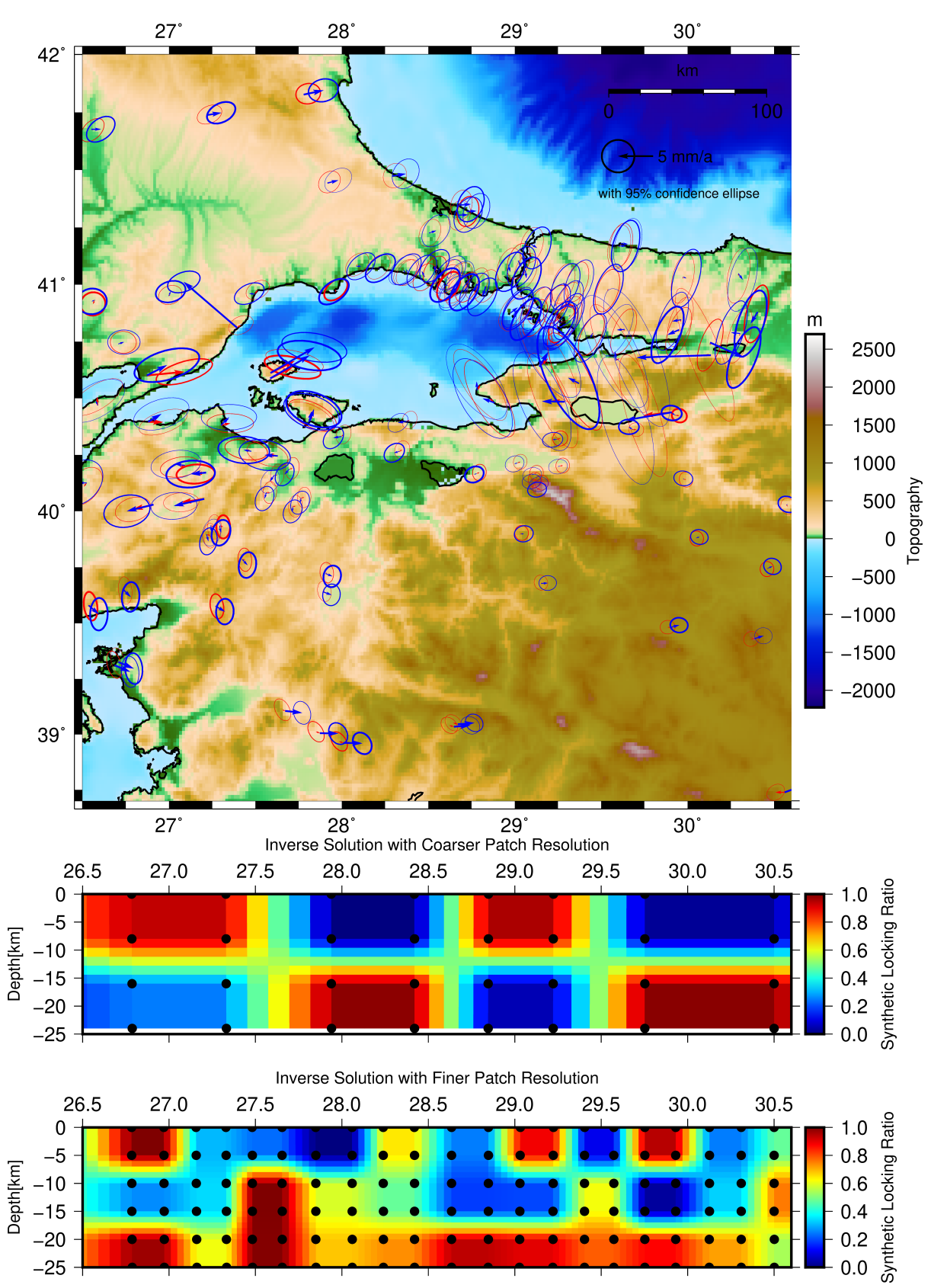

Fig. 6 Results of the checkerboard inversions. In the map, blue arrows and ellipses show the residual velocity and their posterior errors that coming from higher resolution tests respectively. Red arrows and ellipses also indicate the same parameters coming from other test. The above crosssection belongs to the lower resolution (coarse) slip pattern and below one is the finer pattern. 


\subsubsection{Slip Deficit Distribution}

Our purpose here is to resolve the distribution of slip deficit along the MMF using polygonal block models. As far as the block architecture is concerned, one of the important questions was whether the kinematics of the southern NAF fault system impact the inversion results on the MMF. Cases assuming fully locked SNAF from surface to $8 \mathrm{~km}$ depth, assuming a freely sliping SNAF and performing a simultaneous inversion of locking coefficients on both MMF and SNAF were calculated. In this stage, we also did one more inversion combining SMAR and ANAT in a single block, thus removing the SNAF from the calculation (see Fig. 2). All inversions were performed with the same dataset (GPS but no seafloor constraints) and MMF has same node geometry. The slip deficit distributions obtained on the MMF in each case are shown in Fig 7. In the case when the locking distributions on both MMF and SNAF are fitted to data, it appears that the SNAF is locked between $28^{\circ} \mathrm{E}-31^{\circ} \mathrm{E}$ to $\sim 10 \mathrm{~km}$ depth and freely slipping to the west of the $28^{\circ} \mathrm{E}$. It can be concluded that the mechanical behavior of the SNAF has little consequence on the MMF inversion results. More information on these 4 inversions and locking distribution on the SNAF can be found in the supplementary material.
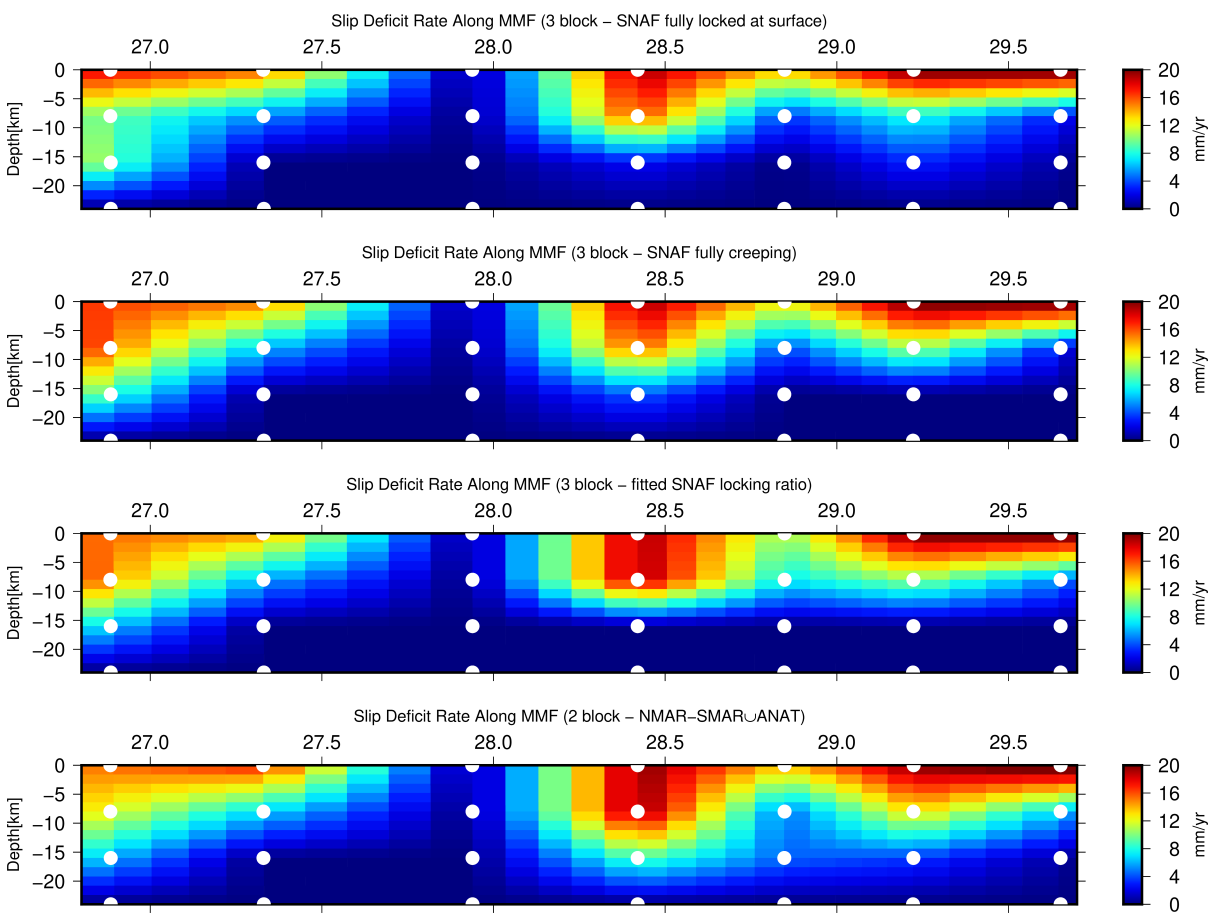

Fig. 7 Cross-sections are shown the slip deficit distribution on the MMF coming from 4 different inversions. White points represent the node distribution on the MMF.

Considering that inversion stability requires using a coarse grid the inversion results are, however, sensitive to the location of the nodes on the fault plane. As will be shown below, given the same number of nodes, varying their spatial distributions 
affects the inversion results while not necessarily leading to drastically different misfits.

In this context, we experimented with three different solutions. The first two solutions aim at understanding the effect of the node locations on the result (spatial density of the nodes was decided from the checkerboard test results). As explained below, after we make a decision for the appropriate node distribution we proceed to investigate the influence of adding seafloor kinematic constraints on the slip rate inversion results.

The two node architectures we tried have the same spatial density and they are laterally shifted by half of cell size (Fig. 8). The nodes are more or less evenly distributed in both cases. These two inversions gave quite similar slip distributions both representing the segmented nature of the MMF. We selected the one having slightly smaller misfit (see Fig. 8 (a) and (b)). The misfits in these two inversions are given in Table 3.

We will now discuss the effect of the added seafloor baseline changes (Yamamoto et al., 2019; Lange et al., 2019) on the slip rate inversions. Fig. 9 (b) and (c)) show the inversion results with and without the added seafloor baseline change constraints. Geometric settings of these two seafloor studies are such that there are four baselines in Yamamoto et al. (2019) and ten baselines in Lange et al. (2019), these are tabulated in the supplementary materials.

Table 3 Total Misfit of the Inversions

\begin{tabular}{lcc}
\hline Dataset & DOF & Misfit \\
\hline Only GPS & 393 & 4.76 \\
Only GPS (shifted half-cell node geometry) & 393 & 4.88 \\
GPS + seafloor data & 407 & 4.78 \\
\hline
\end{tabular}

Despite the fact that the total misfit is slightly worse when the seafloor constraints have been incorporated (see Table 3), there have been some improvements in the misfit of the near-fault GPS stations. In a total of 26 near-coast stations we observed slight improvements to the misfits. This indicates that these seafloor constraints help establishing the near-field elastic effects of the fault slip somewhat better. Table S4 includes the misfit comparison of all GPS sites from inversions both with and without seafloor data. In fact, the solution obtained with added seafloor data is very similar to the solution constrained by GPS only. This emphasizes that the marine geodesy results are compatible with the land data set. In detail, a stronger locking at shallow depth is implied by seafloor data around $28.5^{\circ} \mathrm{E}$, and this also results in a best fitting solution with stronger, and also shallower, locking on the adjacent Prince Island segment $\sim 29^{\circ} \mathrm{E}$. Conversely, a weaker, but deeper coupling is implied at $27.75^{\circ} \mathrm{E}$ below the Western High and also, according to the best fitting solution, westward up to the coast. In this solution, the lowest slip deficit rates are obtained in the Central Basin, where the MMF may be creeping at full rate. Apparently, trade-offs between locking ratio and locking depth leave enough slack in the GPS-constrained solutions to allow fitting the seafloor data as well.

The various solutions obtained all display a contrast in behavior between the western part of the MMF, from the coast at $27.3^{\circ} \mathrm{E}$ to $28.2^{\circ} \mathrm{E}$ east of central basin at 


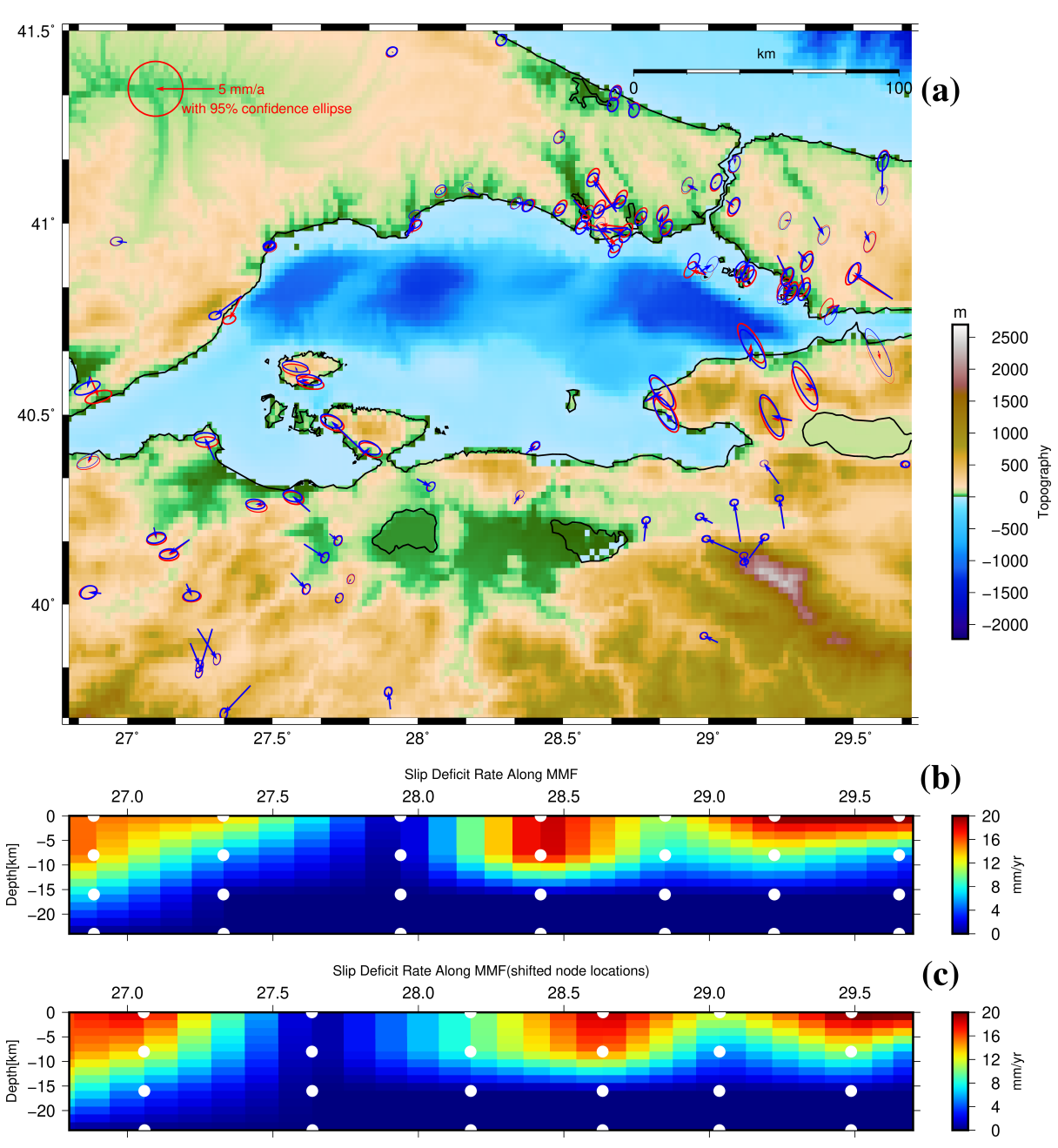

Fig. 8 Inversion comparison according to node locations distribution. (a) Blue arrows is the residual velocities that coming from shifted node geometry solution and red arrows are belong the other inversion. (b) and (c) are the cross-section views of the slip deficit distribution along MMF obtained from these two inversions. White points are the locations of the node points for related model

$27.3^{\circ} \mathrm{E}$ from $27^{\circ} \mathrm{E}$ with weak locking and its eastern part that display strong locking, at least at shallow depths, especially on the Istanbul-Silivri segment and in Izmit Gulf. Within this eastern domain, the Prince Island segment $\sim 29^{\circ}$ E has lower elastic loading, which may be interpreted as either weaker coupling or a shallower base of the locked zone. Over the Sea of Marmara, the base of the locked zone tends to deepen westward, from $5-10 \mathrm{~km}$ below Izmit Gulf to about $10 \mathrm{~km} \sim 28.5^{\circ} \mathrm{E}$ beneath the Central High, to $10-15 \mathrm{~km}$ on the Ganos segment. We should note, however, that the partial locking signal shown in the westernmost part of the domain, reaching the depth of $20 \mathrm{~km}$ is probably an inversion artefact due to a relatively poor GPS coverage there. 


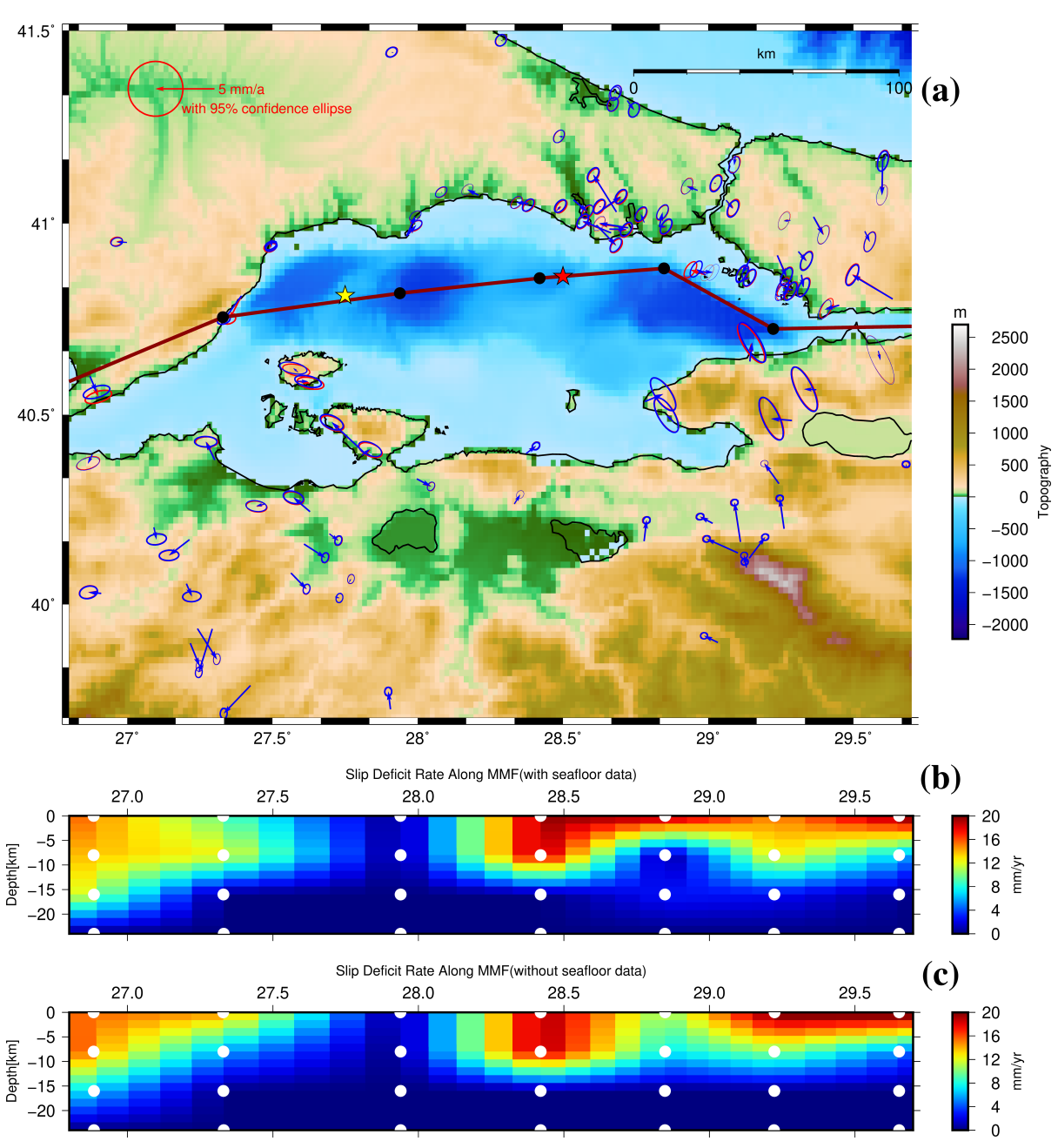

Fig. 9 Inversion comparison according to data. (a) On the map blue and red arrows is the residual velocities of the with/without seafloor data block models respectively. Red line is the fault trace for these inversions and black points are the surface node points. Yellow star is the location where the Yamamoto et al. (2019) stations are and the red star shows the stations of the Lange et al. (2019). The cross-sections (b) and (c) are the slip deficit rate along fault for both inversions respectively

Figure 10 shows, again, the best fitting inversion with a different colour scheme to make it easier to see the seismicity (Schmittbuhl et al., 2016).

\subsection{Continuum Kinematic Model}

Our continuum kinematic model is based on the method described by Beavan and Haines (2001). It is referred to as "continuum" because, unlike the block models, it does not directly involve displacement discontinuities such as faults. It instead aims to fit a continuous strain rate field (using a quadrilateral grid system on the 


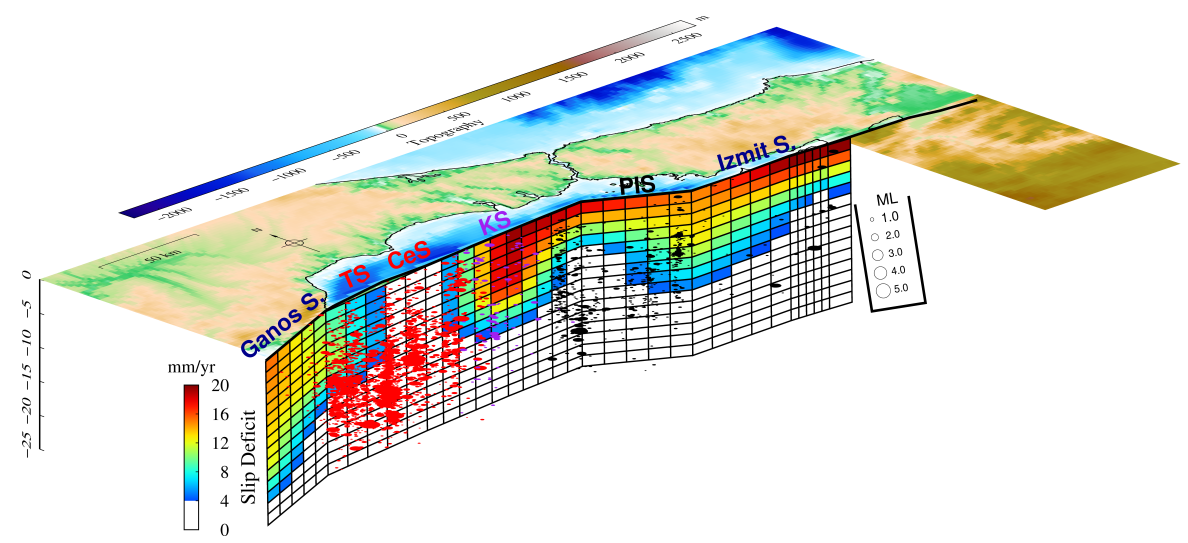

Fig. 10 The cross-section profile is the representation of the slip deficit distribution of the MMF. Circles on the cross-section show the seismicity on the MMF. Red circles represent the earthquakes on the Tekirdag and Central segment (TS-CeS). Blue ones are the earthquakes that occur around the Kumburgaz segment (KS). Seismicity around Prince Island's Segment (PIS) was shown with black circles. Earthquake catalog is taken from Schmittbuhl et al. (2016) and has plotted by scaling according to their magnitude. Blackline on the surface is the illustration of the MMF that coming from our block geometry.

spherical earth) that minimizes RMS misfits for the GPS observations. The penalty function that the method aims to minimize is

$$
\sum_{\text {cells }} \sum_{\alpha \beta, \lambda \mu}\left(\overline{\dot{\varepsilon}}_{\alpha \beta}^{\mathrm{fit}}-\overline{\dot{\varepsilon}}_{\alpha \beta}^{\mathrm{obs}}\right) V_{\alpha \beta, \lambda \mu}^{-1}\left(\overline{\dot{\varepsilon}}_{\lambda \mu}^{\mathrm{fit}}-\overline{\dot{\varepsilon}}_{\lambda \mu}^{\mathrm{obs}}\right)+\sum_{\text {points }} \sum_{\alpha, \beta}\left(v_{\alpha}^{\mathrm{fit}}-v_{\alpha}^{\mathrm{obs}}\right) V_{\alpha, \beta}^{-1}\left(v_{\beta}^{\mathrm{fit}}-v_{\beta}^{\mathrm{obs}}\right)
$$

where $\overline{\dot{\varepsilon}}$ are grid cell-averaged strain rates and $v$ are velocities at GPS locations. Here the first double summation relates to cell-averaged strain rate misfits normalized by an isotropic fourth-order variance-covariance operator. This, in practice, reduces to a summation which can be expressed as

$$
\sum_{\text {cells }} v\left(\dot{\bar{\varepsilon}}_{\phi \phi}^{2}+2 \dot{\bar{\varepsilon}}_{\phi \theta}^{2}+\dot{\bar{\varepsilon}}_{\theta \theta}^{2}\right) S
$$

where the coefficients $v$ control how deformable the material in the particular cell is. In this respect, $v$ coefficients, despite being statistical entities, act like the inverse of linear viscosity in a Newtonian fluid. The $v$ values can, in theory, be different for each grid cell but as explained below, we opted to define single $v$ values for grids covering regions delimited by the blocks given in Fig 2

If there are no independent local constraints on the strain rates (in other word, observed strain rates), then $\overrightarrow{\dot{\varepsilon}}^{\text {obs }}$ strain rate terms are set to zero. In this case the inversion directly attempts to find a minimum strain rate field satisfying the GPS observations. The second double summation goes over all the GPS observations for both components (shown as $\alpha$ and $\beta$ ) normalized by the variance-covariance matrix representing the GPS observation errors. The differential equations that relate the strain rates, on the spherical coordinates, to the rotation functions (using which the velocities are expressed) are given as 


$$
\begin{aligned}
& \dot{\varepsilon}_{\phi \phi}=\frac{\boldsymbol{\Theta}}{\cos \theta} \cdot \frac{\partial \mathbf{W}}{\partial \phi} \\
& \dot{\varepsilon}_{\phi \theta}=\frac{1}{2}\left(\boldsymbol{\Theta} \cdot \frac{\partial \mathbf{W}}{\partial \theta}-\frac{\boldsymbol{\Phi}}{\cos \theta} \cdot \frac{\partial \mathbf{W}}{\partial \phi}\right) \\
& \dot{\varepsilon}_{\theta \theta}=-\boldsymbol{\Phi} \cdot \frac{\partial \mathbf{W}}{\partial \theta}
\end{aligned}
$$

with $\phi$ and $\theta$ being longitude and latitude, respectively. The unit vectors in the east and north directions (Haines and Holt, 1993) are defined as

$$
\begin{aligned}
& \Phi=(-\sin \phi, \cos \phi, 0) \\
& \Theta=(-\sin \theta \cos \phi,-\sin \theta \sin \phi, \cos \theta) .
\end{aligned}
$$

In Eq. (11) the term $\mathbf{W}(\mathbf{r})$ is a rotation function we use to express the horizontal velocity at any point on the earth surface as

$$
\mathbf{v}(\mathbf{r})=\mathbf{W}(\mathbf{r}) \times \mathbf{r} .
$$

In the algorithm the continuity of $\mathbf{W}(\mathbf{r})$ is achieved by means of a bicubic spline expansion on the spherical surface.

\subsubsection{Continuum analysis using the GPS data}

In this section we present three continuum calculations. The first is a best fitting minimum strain rate field using solely the GPS data. The second is a Kostrov summation based strain rate field using the interseismic slip rates calculated in the block model. The third is the strain rate field that corresponds to the residual velocity field in the block model.

The first solution we present uses solely combined GPS data. The fitted GPS field and the corresponding strain rates are displayed in Fig. 11 and Fig. 12 respectively. For this solution we imposed Von Neumann boundary conditions $\left(\partial_{x} u_{x}=0\right)$ in the close vicinity of the MMF at the eastern and western boundaries (shown in Fig. 12 with thick brown lines). We also assumed the northernmost boundary of the grid to be rigid (part of Eurasia, shown in Fig. 12 with thick blue line). Everywhere else we let the values of $\mathbf{W}(\mathbf{r})$ free. We uniformly imposed a $v$ value of 0.035 and the final reduced Chi-squared score for the fit to the GPS was 1.0. This solution is characterized by smooth distributed shear deformation across the Sea of Marmara because the model does not have any constraints within the sea. The inversion also indicates very little deformation to the north of the MMF with the extensional principle axes trending mainly NE-SW. Further north, near the northern boundary of the domain, they become more N-S. To the south of the SNAF the spatial distribution of strain rates are less systematic. Overall, the strain rate styles only partially reflect the large-scale extensions that dominate western Turkey (Özeren and Holt, 2010).

The solution mentioned above does not have any constraints from seafloor geodesy and does not take into account knowledge of offshore structure. A more realistic representation of strain distribution in the Sea of Marmara may be obtained from the block model, in which the deformation is focused along the MMF. For 


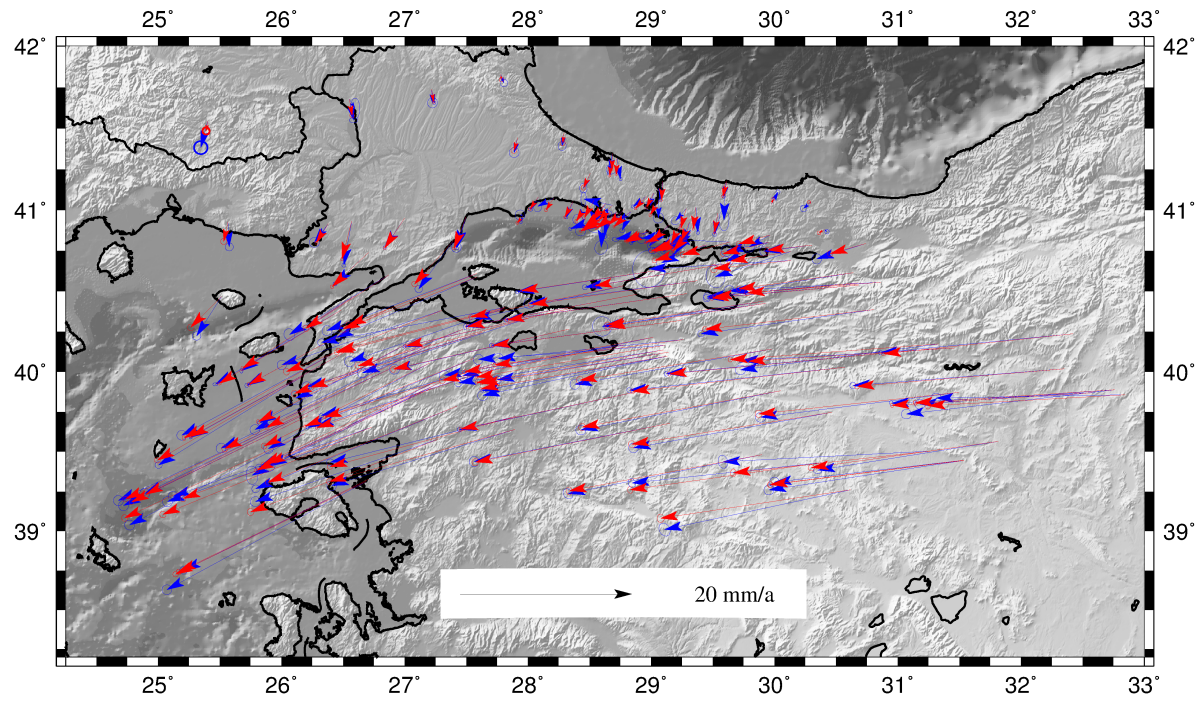

Fig. 11 The observed (blue) and calculated (red) velocities corresponding to the best-fitting block model slip rates given in Fig. 3.

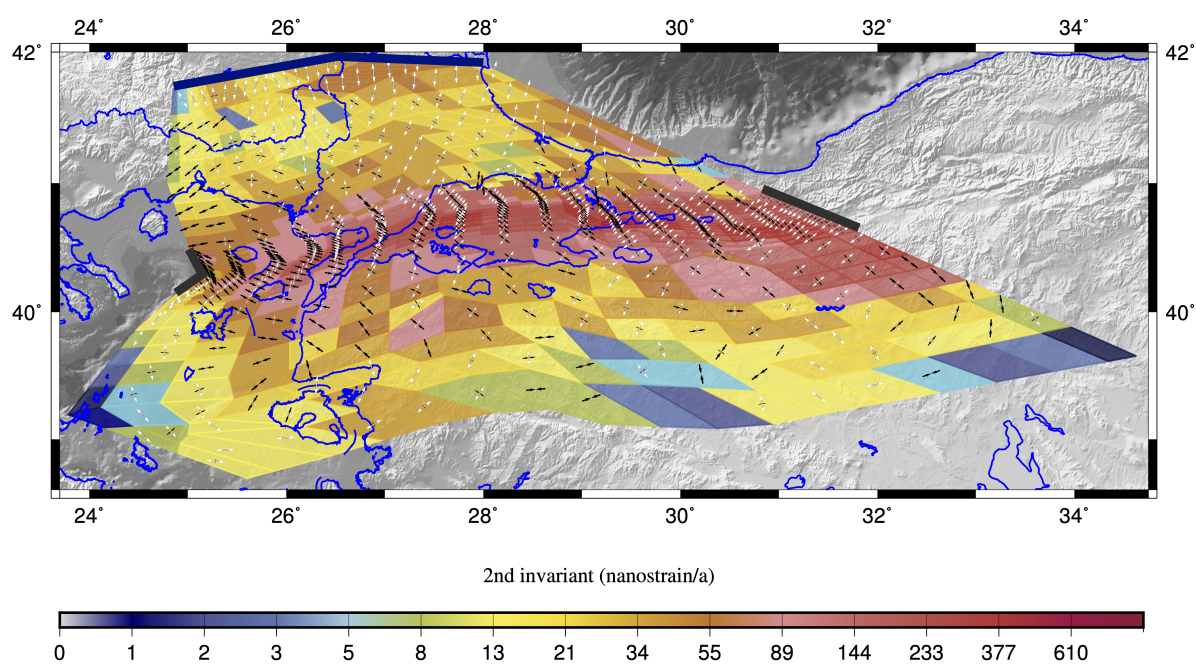

Fig. 12 The strain rates (with the colours indicating the second invariant) corresponding to the solution using the GPS data. The second invariant is defined as $\sqrt{\frac{1}{2}\left(\bar{\varepsilon}_{k l} \bar{\varepsilon}_{k l}\right)}$ with the convention of summation over repeated indices. Thick brown lines both western and eastern boundary of the MMF are the locations where the Von Neumann boundary conditions are imposed. 
this purpose, we use the Kostrov summation (Kostrov, 1974) method to generate a continuum representation of the strain field implied by the block model. We then compare this representation with the GPS-constrained continuum strain field and discuss differences between these models over the land part.

In the Kostrov approach, we use fault plane slip rate distribution on both MMF and SNAF to calculate strain in the deformation zones associated with the block boundaries (Eq. 14). This equation relates the seismic moment tensor to the grid cell area-averaged strain rates:

$$
\overline{\dot{\epsilon}}_{i j}=\frac{1}{2} \sum_{k=1}^{n} \frac{L_{k} \dot{u}_{k}}{\sin \delta_{k}} m_{i j}^{k}
$$

where $\mathrm{n}$ is the number of fault segments, each having length $L_{k}$, dip angle $\delta_{k}$ and slip rate $\dot{u}_{k}$ in the grid cell area and $m_{i j}$ is the unit moment tensor defined by the fault orientation and the unit slip vector. In addition, when we calculate this Kostrov solution, we preconditioned the solution outside the MMF and SNAF deformation zones by assigning apriori strain rates (see Eq. 9) equal to the block strain rates obtained in the best fitting block model (see Fig. 3). Internal block deformation in the block model is crudely approximated as uniform strain. Block principal strain orientations, with NE-SW extension and NW-SE compression are consistent with right lateral shearing in the NAF zone. The SMAR block between MMF and SNAF has the largest strain rates (38 nanostrain/yr). The NMAR block has only a very small component of extension of less than 10 nanostrain/yr.

Fig. 13 shows the strain rate field corresponding to this solution. By construction, strain is more focused on the MMF in the Kostrov model and reaching about 1 microstrain/yr. Hence, strain outside the principal shear zone of the MMF is on average lower in this model than in the GPS-constrained continuum model, but remains in the 30-50 nanostrain/yr range in a broad zone comprising the SNAF and the SMAR block. Unlike the MMF, the SNAF does not appear as a prominent concentration of strain relative to the background. In the Kostrov model, this is related to assumptions on strain distribution through the choice of a broader cell size. In the GPS-constrained model, the SNAF does not appear as a continuous swath of higher strain. While this may be in part related to noise, it is consistent with the structure of the SNAF system that appears as a discontinuous set of faults within a shear zone, especially in the western part of the study area. This raises the question of whether these residual shear patterns are a result of unmodeled fault slip rate or perhaps indicate that there is a significant broad $(10 \mathrm{~s}-100 \mathrm{~s} \mathrm{~km})$ shear zone around the MMF/SNAF, either consisting of many minor fault structures accommodating the same slip patterns or real continuous deformation between the major faults. Nevertheless, the continuum solution calculated from the GPS data indicates that, at least on land, part of the strain field cannot be explained by the elastic loading of the main faults. In both models, deformation between $28^{\circ} \mathrm{E}$ and $30^{\circ} \mathrm{E}$ mostly occurs north of the SNAF as specified in the block model (along the Southern shore of the Sea of Marmara, through Gemlik Bay, and along Iznik Lake). However, west of $28^{\circ} \mathrm{E}$ the deformation zone broadens as the SMAR block widens and also spreads further south into the ANAT block. The two models display larger differences East of $30^{\circ} \mathrm{E}$, where the GPS-constrained model finds significant strain in the ANAT block, while most of the deformation in the block model is focused between MMF and SNAF. 


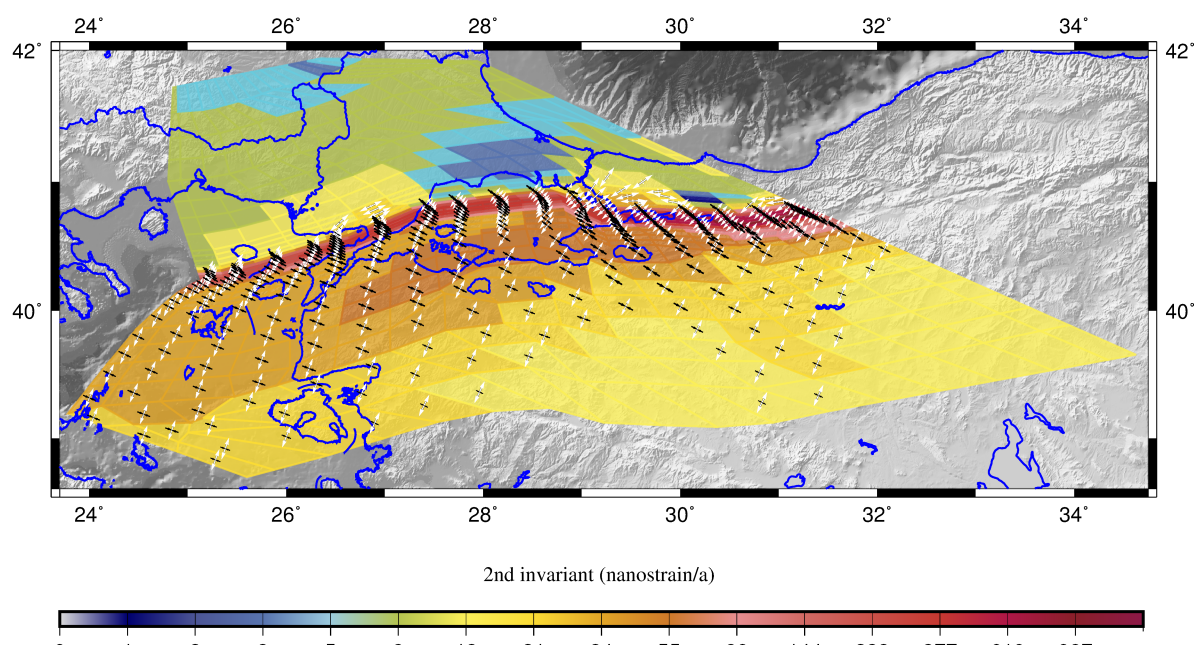

Fig. 13 Second invariant of the strain rates obtained from Kostrov model. Strain crosses are plotted for grid cells that have only larger than 20 nanostrain/yr.

\subsubsection{Continuum interpretation of the block model misfits}

The best-fitting block model velocity outputs at the GPS observation locations are used to calculate the velocity misfits at these locations. We then used these misfits to calculate a continuous strain rate field. The strain rate field associated with these velocity residuals is given in Fig. 14. The figure shows that the strain rates associated with the misfits are reasonably small in the Sea of Marmara except the eastern part of it. This might be partially due to the inconsistencies created by some post-seismic effects on the velocity field around the Izmit Gulf. Some of the GPS velocities that we use there date back to a period before the 1999 Izmit and Düzce earthquakes.The relatively large misfit strain rates to the SE of the Izmit Gulf might be due to the fact that the block model architecture does not take any active faults in this region into account. Other patches of increased strain occur west of $28^{\circ} \mathrm{E}$ and south of the location of the SNAF in the block model. These correspond to known seismically active fault which are part of the SNAF system, comprising Edremit Fault and Yenice-Gönen Fault (Kurcer et al., 2019).

\section{Discussion}

In this study, our purpose was to combine the land GPS observations with the recent seafloor geodetic observations to depict a kinematic picture of the faulting in the Sea of Marmara including the distribution of locking. Our main result is that the complete data set may be explained supposing that the part of the MMF west of $28.2^{\circ} \mathrm{E}$ is experiencing long term aseismic creep while the eastern part is essentially locked, but with variable locking depth. A lack of elastic loading at several GPS stations North of the Sea of Marmara was already noticed by Le Pichon et al. (2003) and interpreted as due to contrasting elastic properties across the fault. Ergintav 


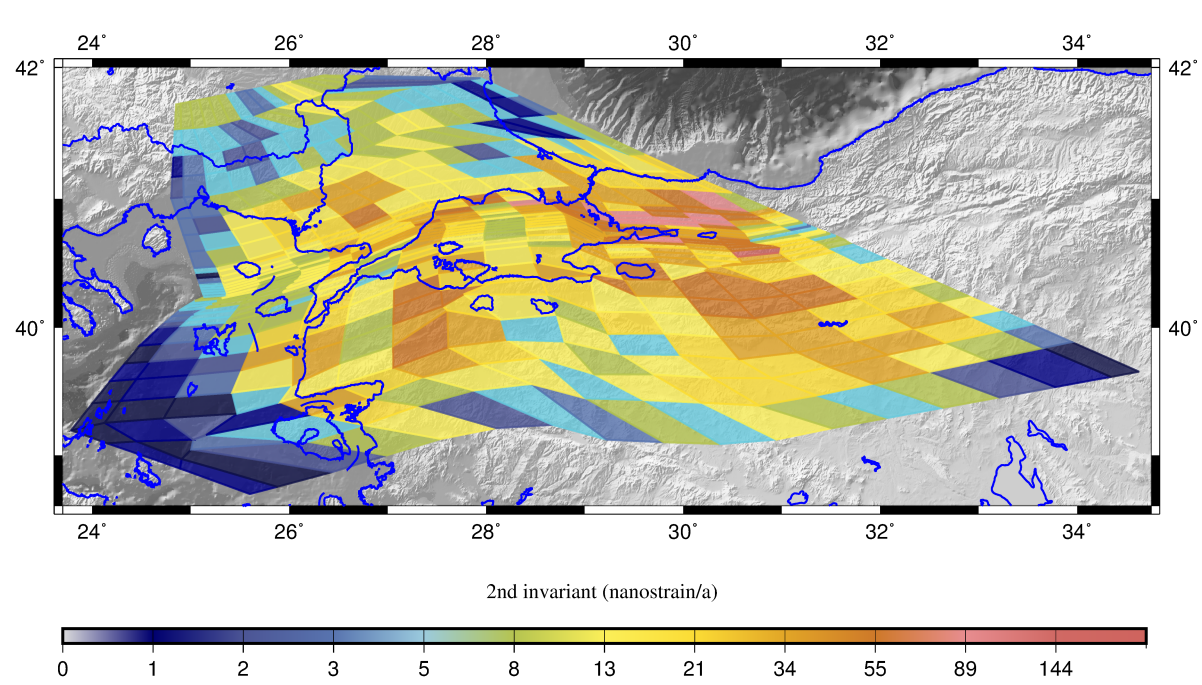

Fig. 14 The second invariant of the strain rate field corresponding to the velocity misfits from the block model.

et al. (2014) proposed that the slip deficit rate on the central segment of the MMF was in fact very low based on 2D models (projecting GPS data on cross sections), but could not establish the exact distribution of aseismic creep. Klein et al. (2017) showed that the fault segments where a high creep rate could be inferred were also those with the largest uncertainty, but that resolution could be increased with more stations. A more recent inversion of GPS data (Bulut et al., 2019) found a locking distribution somewhat similar to our results. They find a zone of high locking on the central segment, but around $28^{\circ} \mathrm{E}-28.3^{\circ} \mathrm{E}$ while ours is centered around $28.5^{\circ} \mathrm{E}$. However, uncertainties regarding the exact location and size of the locked zones remain important when only land data are considered. In detail, the slip distribution in Bulut et al. (2019) would result in partial locking at the Western High seafloor site as well as the Kumburgaz seafloor site (respectively $8 \mathrm{~mm} / \mathrm{yr}$ and $10 \mathrm{~mm} / \mathrm{yr}$ slip deficit), which is not compatible with the marine geodesy results.

The seafloor geodetic study of Yamamoto et al. (2019) (the location shown with a yellow star on Fig. 9 (a)) concluded that there is a partial creep of $10.7 \pm 4.7 \mathrm{~mm} / \mathrm{yr}$ in the surface sedimentary layer. Furthermore, they propose to fit both land and marine data with a model of exponential decrease of creep rate with depth, reaching complete locking at a depth of about $8 \mathrm{~km}$. Below $11 \mathrm{~km}$, they assume the fault is freely slipping again. In fact, our results suggest that a fully locked depth interval may not be required at this location. Our best-fitting model gives a surface slip rate of $15.3 \mathrm{~mm} / \mathrm{yr}$, decreasing down to $11.2 \mathrm{~mm} / \mathrm{yr}$ at $8-9 \mathrm{~km}$ and increasing again deeper down to reach nearly freely slipping conditions around $12 \mathrm{~km}$ (Fig. 9 (b)). Note that the inversion using solely the land GPS data fails to capture these variations of locking ratio with depth (Fig. 9 (c)). The seafloor geodetic study of Lange et al. (2019) (yellow star on Fig. 9 (a)) indicates a complete locking of the fault at the surface in Kumburgaz Basin. They conclude that the seafloor baseline changes justify a locking that reaches at least $3-3.5 \mathrm{~km}$. Our results indicate an almost complete locking down to $10 \mathrm{~km}$ at this location. Our locking depth estimation is less 
than $10 \mathrm{~km}$ under the Prince Island segment. This is less than estimated with GPSbased one-dimensional models by Ergintav et al. (2014) and from microseismicity distribution Bohnhoff et al. (2013). However, there are trade offs involved in the inversion between locking depth and locking ratio, so that consideration of partial locking above $10 \mathrm{~km}$ could reconcile all observations. Further east, within the western part of the Izmit bay, full locking at the surface is obtained. In this area, several studies using GPS and/or InSAR found surface post-seismic creep in the Izmit segment after the 1999 earthquakes, suggesting its decreasing effect over time (Ergintav et al., 2009; Çakir et al., 2012; Aslan et al., 2019). Our model could not resolve this creep signal. One possible reason is that our data set in this area includes GPS stations that were measured before the 1999 ruptures.

Fig. 10 shows seismicity overlaid on the distribution of slip deficit on the MMF obtained with the block model. The relatively high seismic activity in the Western Sea of Marmara has been attributed to creep (Schmittbuhl et al., 2016). This interpretation is further supported by the occurrence of seismic repeaters at crustal depths and at several locations (Schmittbuhl et al., 2016; Bohnhoff et al., 2017; Uchida et al., 2019). Clustered repeater activity below the Central Basin indicates high creep rate, possibly close to long term fault velocity (Schmittbuhl et al., 2016). The locking distribution from our geodetic inversion result is consistent with these results. Furthermore, it is seen that seismicity is subdued in the eastern part of the Central segment (Schmittbuhl et al., 2016; Wollin et al., 2018) and that corresponds to a well locked patch in our inversion. Indeed, the fault is locked around $28.5^{\circ} \mathrm{E}$ from surface to the depth of $\sim 15 \mathrm{~km}$ according to our inversion. On the other hand, our slip distribution does not match the distribution of seismicity on the Prince's Island Segment (see Fig. 10). On this segment, an arc-shaped zone of active microseismicity delineates an aseismic zone, which is inferred to be a locked asperity (Bohnhoff et al., 2013). However, our model may not have enough resolution to resolve this asperity. Moreover, the seismic activity observed here is not an indicator of steady creep, as repeaters were not observed, and most of the seismicity occurs off the main fault plane (Wollin et al., 2018). Considering that the relatively intense seismic activity there could arise due to stress concentration at fault bends and occurrence of extension and strain partitioning along this oblique segment, the locking distribution we obtain in this area may still be meaningful.

\section{Conclusion}

Combined inversion of land GPS data and seafloor acoustic baseline data with a block model approach provide a comprehensive understanding of long term fault kinematics, interseismic fault loading and an aseismic creep. Furthermore, a tandem continuum model shed light on the deformation patterns which are not easily detected if one solely uses a block model approach. In our study, this is particularly useful to see the details of the broad shear zone between the MMF and SNAF.

The long term fault velocities calculated for the Main Marmara Fault and the Southern branch of the North Anatolian Fault are at the upper bound of geologically determined slip rates at $19-20 \mathrm{~mm} / \mathrm{yr}$ along the offshore part of the MMF and 3-4 mm/yr on the SNAF. Both fault systems are dominantly strike-slip with the exception of the Prince Island segment, where the obliquity exceeds $20 \%$. In the block model, all the relative motion between two blocks occurs on a single discontinuity, 
and this may explain why calculated rates are at the upper bound of observed fault rates because secondary faults and splays may take up a relatively small, but still significant, part of the tectonic strain. However, the SNAF system differ from the MMF in that it appears as a $50 \mathrm{~km}$ wide zone of deformation with a patchy distribution of strain reflecting the activity of individual faults. Furthermore, both the continuum and the block models indicate that the whole interval between the MMF and the SNAF is deforming, with strain rates of several tens of nanostrain per year, corresponding to several $\mathrm{mm} / \mathrm{yr}$ in the western part of the model where this interval is $100 \mathrm{~km}$ wide. Except in its western part, the SNAF system appears dominantly locked and assumptions on its behavior only have limited influence on inversion results obtained on the MMF. The MMF displays aseismic creep in the Western part of the Sea of Marmara and may be creeping at nearly full block velocity in the Central Basin. On the other hand, it appears locked from the seafloor to a depth of about $10 \mathrm{~km}$ east of $28.2^{\circ} \mathrm{E}$. Because the locking ratio is interpolated on a coarse grid, our inversion brings no new insight on the Prince Islands segment. On the Izmit segment determination of steady-state parameters is obfuscated by time varying post-seismic creep following 1999 earthquake. As we show that the Istanbul-Silivri segment is nominally locked. The existence of a hazardous seismic gap in the Sea of Marmara, potentially yielding a magnitude 7.5 event, is confirmed. Fault segments with active creep at crustal level often constitute barrier to earthquake rupture propagation (Rice, 1993; Perfettini et al., 2010). However, rupture propagation on creeping segments has also been documented in various contexts (Cakir et al., 2005; Noda and Lapusta, 2013; Harris, 2017). Therefore, occurrence of creep on the Western MMF segment does not preclude propagation of seismic ruptures on this part of the fault. Nevertheless, our inversion finds that creep occurs at a rate close to the long term fault rate beneath the Central Basin and an analysis of repeating events (Schmittbuhl et al., 2016) reached the same conclusion. A nearly complete lack of elastic loading in the Central Basin may indicate a barrier to rupture propagation. In this view the Central Basin could constitute a segment boundary, not only because it presents a minor bend on the MMF, but also because of varying fault material properties at crustal level.

The continuum model in this study revealed that the inelastic strain rates outside the MMF principal shear zone are not large, however they are nevertheless in the range of 30-50 nanostrain/yr between the MMF and SNAF. In the southernmost part of the computational domain, there is a significant discrepancy between the GPS and Kostrov solutions, though the average strain rate magnitudes are quite similar. One interpretation of this is that the transition from the broad shear regime into a more extension-dominated regime further south is indeed controlled by a discontinuous series of active fault structures (Yaltirak et al., 2002) or factors other than the prominent fault system to the north.

The present study shows that a tandem approach, using both block and continuum models are advantageous especially in situations where parts of the deforming region lack GPS data. The tandem approach can therefore be instrumental in producing a more refined view of the deformation field which has implications for seismic hazard studies. A possible future research direction is to exploit the more accurate analytical techniques such as (Nikkhoo and Walter, 2015) in sea-covered regions in near field and in a separate analysis match the far field deformation indicators using a continuum model such as the one used in this study. Moreover, 
fusion of the block and continuum models should be performed more routinely in actively deforming regions around the globe.

Acknowledgements We are grateful to Dr. Semih Ergintav and Dr. Cengiz Zabcı for sharing their valuable ideas with us. We also thank to Dr. Attila Çiner and anonymous reviewers who helped us improve the manuscript. Financial support was provided by the bilateral ANR/TUBITAK collaborative research project MAREGAMI (ANR-16-CE03-0010-02 and Tubitak Project 116Y371) and EMSO-Link project (EU H2020 grant agreement 731036). All of the figures are plotted by using the General Mapping Tools (Wessel et al., 2019). In order to define the reference block in the block model inversion, we used GPS sites from Blewitt et al. (2018).

\section{References}

Aktuğ B, Parmaksiz E, Kurt M, Lenk O, Kiliçoǧlu A, Ali Gürdal M, Özdemir S (2013) Deformation of Central Anatolia: GPS Implications. Journal of Geodynamics 67:78-96, DOI 10.1016/j.jog.2012.05.008

Altamimi Z, Sillard P, Boucher C (2002) ITRF2000: A new release of the International Terrestrial Reference Frame for earth science applications. Journal of Geophysical Research: Solid Earth 107(B10):ETG 2-1-ETG 2-19, DOI 10.1029/2001jb000561

Altamimi Z, Métivier L, Collilieux X (2012) ITRF2008 plate motion model. Journal of Geophysical Research: Solid Earth 117(7):1-14, DOI 10.1029/2011JB008930

Altamimi Z, Métivier L, Rebischung P, Rouby H, Collilieux X (2017) ITRF2014 plate motion model. Geophysical Journal International 209(3):1906-1912, DOI 10.1093/gji/ggx136

Armijo R, Meyer B, Navarro S, King G, Barka A (2002) Asymmetric slip partitioning in the Sea of Marmara pull-apart: a clue to propagation processes of the North Anatolian Fault? Terra Nova 14(2):80-86, DOI 10.1046/j.1365-3121.2002.00397.x, URL http://doi.wiley.com/10.1046/j.13653121.2002.00397.x

Aslan G, Lasserre C, Cakir Z, Ergintav S, Özarpaci S, Dogan U, Bilham R, Renard F (2019) Shallow Creep Along the 1999 Izmit Earthquake Rupture (Turkey) From GPS and High Temporal Resolution Interferometric Synthetic Aperture Radar Data (2011-2017). Journal of Geophysical Research: Solid Earth 124(2):2218-2236, DOI 10.1029/2018JB017022, URL https://onlinelibrary.wiley.com/doi/abs/10.1029/2018JB017022

Beavan J, Haines J (2001) Contemporary horizontal velocity and strain rate fields of the Pacific-Australian plate boundary zone through New Zealand. Journal of Geophysical Research: Solid Earth 106(B1):741-770, DOI 10.1029/2000jb900302

Bécel A, Laigle M, de Voogd B, Hirn A, Taymaz T, Galvé A, Shimamura H, Murai Y, Lépine JC, Sapin M, Özalaybey S (2009) Moho, crustal architecture and deep deformation under the North Marmara Trough, from the SEISMARMARA Leg 1 offshore-onshore reflection-refraction survey. Tectonophysics 467(1-4):1-21, DOI 10.1016/j.tecto.2008.10.022, URL http://dx.doi.org/10.1016/j.tecto.2008.10.022

Blewitt G, Hammond WC, Kreemer C (2018) Harnessing the gps data explosion for interdisciplinary science. Eos 99:1-2, DOI 10.1038/s41467-017-01440-4

Bohnhoff M, Bulut F, Dresen G, Malin PE, Eken T, Aktar M (2013) An earthquake gap south of Istanbul. Nature Communications 4(1):1999, DOI 
10.1038/ncomms2999, URL http://www.ncbi.nlm.nih.gov/pubmed/23778720 http://www.nature.com/doifinder/10.1038/ncomms2999

http://www.nature.com/articles/ncomms2999

Bohnhoff M, Wollin C, Domigall D, Küperkoch L, Martínez-Garzón P, Kwiatek G, Dresen G, Malin PE (2017) Repeating Marmara Sea earthquakes: indication for fault creep. Geophysical Journal International 210(1):332339, DOI 10.1093/gji/ggx169, URL https://academic.oup.com/gji/articlelookup/doi/10.1093/gji/ggx169

Bouchon M, Karabulut H, Aktar M, Ozalaybey S, Schmittbuhl J, Bouin MP (2011) Extended Nucleation of the $1999 \mathrm{Mw} 7.6$ Izmit Earthquake. Science 331(6019):877-880, DOI 10.1126/science.1197341, URL http://www.sciencemag.org/cgi/doi/10.1126/science.1197341

Bulut F, Aktuğ B, Yaltırak C, Doğru A, Özener H (2019) Magnitudes of future large earthquakes near Istanbul quantified from 1500 years of historical earthquakes, present-day microseismicity and GPS slip rates. Tectonophysics 764(July 2018):77-87, DOI 10.1016/j.tecto.2019.05.005, URL https://doi.org/10.1016/j.tecto.2019.05.005 https://linkinghub.elsevier.com/retrieve/pii/S0040195119301908

Çakir Z, de Chabalier JB, Armijo R, Meyer B, Barka A, Peltzer G (2003) Coseismic and early post-seismic slip associated with the 1999 Izmit earthquake (Turkey), from SAR interferometry and tectonic field observations. Geophysical Journal International 155(1):93-110, DOI 10.1046/j.1365-246X.2003.02001.X

Cakir Z, Akoglu AM, Belabbes S, Ergintav S, Meghraoui M (2005) Creeping along the ismetpasa section of the north anatolian fault (western turkey): Rate and extent from insar. Earth and Planetary Science Letters 238(1):225-234, DOI https://doi.org/10.1016/j.epsl.2005.06.044, URL https://www.sciencedirect.com/science/article/pii/S0012821X05004255

Çakir Z, Ergintav S, Özener H, Dogan U, Akoglu AM, Meghraoui M, Reilinger $\mathrm{R}(2012)$ Onset of aseismic creep on major strike-slip faults. Geology 40:11151118, DOI 10.1130/G33522.1

Emre Ö, Duman T, Özalp S, Elmacı H, Olgun Ş, Şaroğlu F (2013) Active fault map of turkey with explanatory text. General Directorate of Mineral Research and Exploration Special Publication Series 30

Emre Duman TY, Özalp S, Şaroğlu F, Olgun Elmacı H, Çan T (2018) Active fault database of Turkey. Bulletin of Earthquake Engineering 16(8):3229-3275, DOI 10.1007/s10518-016-0041-2, URL http://link.springer.com/10.1007/s10518016-0041-2

Ergintav S, McClusky S, Hearn E, Reilinger R, Cakmak R, Herring T, Ozener H, Lenk O, Tari E (2009) Seven years of postseismic deformation following the 1999, $M=7.4$ and $M=7.2$, Izmit-Düzce, Turkey earthquake sequence. Journal of Geophysical Research 114(B7):B07403, DOI 10.1029/2008JB006021, URL http://doi.wiley.com/10.1029/2008JB006021

Ergintav S, Reilinger RE, Çakmak R, Floyd M, Cakir Z, Doğan U, King RW, McClusky S, Özener H (2014) Istanbul's earthquake hot spots: Geodetic constraints on strain accumulation along faults in the Marmara seismic gap. Geophysical Research Letters 41(16):5783-5788, DOI 10.1002/2014GL060985, URL http://doi.wiley.com/10.1002/2014GL060985

Flerit F, Armijo R, King GCP, Meyer B, Barka A (2003) Slip partitioning in the Sea of Marmara pull-apart determined from GPS velocity vectors. Geophysical Journal 
International 154:1-7, DOI 10.1046/j.1365-246X.2003.01899.x

Gasperini L, Polonia A, Bortoluzzi G, Henry P, Le Pichon X, Tryon M, Çağatay N, Géli L (2011) How far did the surface rupture of the 1999 İzmit earthquake reach in Sea of Marmara? Tectonics 30(1), DOI 10.1029/2010TC002726

Grall C (2013) La Faille Nord Anatolienne dans sa portion immergée en mer de Marmara : évolution du réseau de failles et migration de fluides. PhD thesis, AixMarseille Université

Haines AJ, Holt WE (1993) A procedure for obtaining the complete horizontal motions within zones of distributed deformation from the inversion of strain rate data. Journal of Geophysical Research 98(B7), DOI 10.1029/93jb00892

Harris RA (2017) Large earthquakes and creeping faults. Reviews of Geophysics 55(1):169-198, DOI 10.1002/2016RG000539

Hergert T, Heidbach $\mathrm{O}$ (2010) Slip-rate variability and distributed deformation in the Marmara Sea fault system. Nature Geoscience 3(2):132-135, DOI 10.1038/ngeo739, URL http://dx.doi.org/10.1038/ngeo739

Hergert T, Heidbach O (2011) Geomechanical model of the Marmara Sea regionII. 3-D contemporary background stress field. Geophysical Journal International 185:1090-1102, DOI 10.1111/j.1365-246X.2011.04992.x

Hergert T, Heidbach O, Bécel A, Laigle M (2011) Geomechanical model of the Marmara Sea region-I. 3-D contemporary kinematics. Geophysical Journal International 185:1073-1089, DOI 10.1111/j.1365-246X.2011.04991.x

Herring TA, King RW, Floyd MA, McClusky SC (2018) Introduction to GAMIT/GLOBK, Release 10.7 (June 2018):1-50

Hubert-Ferrari A, Armijo R, King G, Meyer B, Barka A (2002) Morphology, displacement, and slip rates along the North Anatolian Fault, Turkey. Journal of Geophysical Research: Solid Earth 107(B10):9-1, DOI 10.1029/2001JB000393, URL http://doi.wiley.com/10.1029/2001JB000393

Klein E, Duputel Z, Masson F, Yavasoglu H, Agram P (2017) Aseismic slip and seismogenic coupling in the Marmara Sea: What can we learn from onland geodesy? Geophysical Research Letters 44(7):3100-3108, DOI 10.1002/2017GL072777, URL http://doi.wiley.com/10.1002/2017GL072777

Kostrov V (1974) Seismic moment and energy of earthquakes, and seismic flow of rock. Izv Acad Sci USSR Phys Solid Earth, Engl Transl 1:23-44

Kurcer A, Özalp S, Özdemir E, Guldogan ÇU, Duman TY (2019) Active tectonic and paleoseismologic characteristics of the yenice-gönen fault, nw turkey, in light of the 18 march 1953 yenice-gönen earthquake $(\mathrm{ms}=7.2)$. Maden Tetkik ve Arama Dergisi 159(159):29-62

Kurt H, Sorlien CC, Seeber L, Steckler MS, Shillington DJ, Cifci G, Cormier MH, Dessa JX, Atgin O, Dondurur D, Demirbag E, Okay S, Imren C, Gurcay S, Carton H (2013) Steady late quaternary slip rate on the Cinarcik section of the North Anatolian fault near Istanbul, Turkey. Geophysical Research Letters 40(17):4555-4559, DOI 10.1002/grl.50882

Lange D, Kopp H, Royer JY, Henry P, Çakir Z, Petersen F, Sakic P, Ballu V, Bialas J, Özeren MS, Ergintav S, Géli L (2019) Interseismic strain build-up on the submarine North Anatolian Fault offshore Istanbul. Nature Communications 10(1):3006, DOI 10.1038/s41467019-11016-z, URL http://dx.doi.org/10.1038/s41467-019-11016-z http://www.nature.com/articles/s41467-019-11016-z 
Le Pichon $X$, Şengör A, Demirbağ E, Rangin C, İmren C, Armijo R, Görür N, Çağatay N, Mercier de Lepinay B, Meyer B, Saatçılar R, Tok B (2001) The active Main Marmara Fault. Earth and Planetary Science Letters 192(4):595-616, DOI 10.1016/S0012-821X(01)00449-6, URL http://linkinghub.elsevier.com/retrieve/pii/S0012821X01004496

Le Pichon X, Chamot-Roooke N, Rangin C, Sengör AMC (2003) The North Anatolian fault in the Sea of Marmara. Journal of Geophysical Research 108:2179, DOI 10.1029/2002JB001862

Le Pichon X, Şengör AC, Kende J, İmren C, Henry P, Grall C, Karabulut H (2016) Propagation of a strike-slip plate boundary within an extensional environment: the westward propagation of the North Anatolian Fault. Canadian Journal of Earth Sciences 53(11):1416-1439, DOI 10.1139/cjes-2015-0129, URL http://www.nrcresearchpress.com/doi/10.1139/cjes-2015-0129

Lines L, Treitel S (1984) A review of least-squares inversion and its application to geophysical problems. Geophysical prospecting 32(2):159-186, DOI 10.1111/j.1365-2478.1984.tb00726.x

McCaffrey R (2002) Crustal block rotations and plate coupling. Plate Boundary Zones, Geodyn Ser 30:101-122, DOI 10.1029/GD030p0101

McCaffrey R, Qamar AI, King RW, Wells R, Khazaradze G, Williams CA, Stevens CW, Vollick JJ, Zwick PC (2007) Fault locking, block rotation and crustal deformation in the Pacific Northwest. Geophysical Journal International 169(3):13151340, DOI 10.1111/j.1365-246X.2007.03371.x

Meade BJ (2002) Estimates of Seismic Potential in the Marmara Sea Region from Block Models of Secular Deformation Constrained by Global Positioning System Measurements. Bulletin of the Seismological Society of America 92(1):208-215, DOI 10.1785/0120000837, URL https://pubs.geoscienceworld.org/bssa/article/92/1/208-215/102935

Nikkhoo M, Walter TR (2015) Triangular dislocation: an analytical, artefactfree solution. Geophysical Journal International 201(2):1119-1141, DOI 10.1093/gji/ggv035, URL https://doi.org/10.1093/gji/ggv035

Noda H, Lapusta N (2013) Stable creeping fault segments can become destructive as a result of dynamic weakening. Nature 493(7433):518-521, DOI 10.1038/nature11703, URL https://doi.org/10.1038/nature11703

Okada Y (1985) Surface deformation due to shear and tensile faults in a half-space. Bulletin of the Seismological Society of America 75(4):1135-1154

Okada Y (1992) Internal deformation due to shear and tensile faults in a half-space. Bulletin of the Seismological Society of America 82(2):1018-1040

Okay S, Aydemir S (2016) Control of active faults and sea level changes on the distribution of shallow gas accumulations and gas-related seismic structures along the central branch of the North Anatolian Fault, southern Marmara shelf, Turkey. Geodinamica Acta 28(4):328-346, DOI 10.1080/09853111.2016.1183445

Özdemir S (2016) Tusaga ve tusaga-aktif istasyonlarının hassas koordinat ve hızlarının hesaplanması üzerine. Harita Dergisi 155

Özeren MS, Holt WE (2010) The dynamics of the eastern Mediterranean and eastern Turkey. Geophysical Journal International 183:1165-1184, DOI 10.1111/j.1365-246X.2010.04819.x

Parsons T (2004) Recalculated probability of M 7 earthquakes beneath the Sea of Marmara, Turkey. Journal of Geophysical Research: Solid Earth 109(B5):1-21, DOI 10.1029/2003JB002667, URL http://doi.wiley.com/10.1029/2003JB002667 
Perfettini H, Avouac JP, Tavera H, Kositsky A, Nocquet JM, Bondoux F, Chlieh M, Sladen A, Audin L, Farber DL, Soler P (2010) Seismic and aseismic slip on the Central Peru megathrust. Nature 465(7294):78-81, DOI 10.1038/nature09062, URL https://doi.org/10.1038/nature09062

Polonia A, Gasperini L, Amorosi A, Bonatti E, Bortoluzzi G, Çagatay N, Capotondi L, Cormier MH, Gorur N, McHugh C, Seeber L (2004) Holocene slip rate of the North Anatolian Fault beneath the Sea of Marmara. Earth and Planetary Science Letters 227:411-426, DOI 10.1016/j.epsl.2004.07.042

Pondard N, Armijo R, King GCP, Meyer B, Flerit F (2007) Fault interactions in the Sea of Marmara pull-apart (North Anatolian Fault): Earthquake clustering and propagating earthquake sequences. Geophysical Journal International 171:11851197, DOI 10.1111/j.1365-246X.2007.03580.x

Press WH, Flannery BP, Teukolsky SA, Vetterling WT, et al. (1989) Numerical recipes, vol 3. Cambridge University Press Cambridge

Rangin C, Le Pichon X, Demirbag E, Imren C (2004) Strain localization in the Sea of Marmara: Propagation of the North Anatolian Fault in a now inactive pull-apart. Tectonics 23:1-18, DOI 10.1029/2002TC001437

Reilinger R, McClusky S, Vernant P, Lawrence S, Ergintav S, Cakmak R, Ozener H, Kadirov F, Guliev I, Stepanyan R, Nadariya M, Hahubia G, Mahmoud S, Sakr K, ArRajehi A, Paradissis D, Al-Aydrus a, Prilepin M, Guseva T, Evren E, Dmitrotsa A, Filikov SV, Gomez F, Al-Ghazzi R, Karam G (2006) GPS constraints on continental deformation in the Africa-Arabia-Eurasia continental collision zone and implications for the dynamics of plate interactions. Journal of Geophysical Research: Solid Earth 111:1-26, DOI 10.1029/2005JB004051

Rice JR (1993) Spatio-temporal complexity of slip on a fault. Journal of Geophysical Research 98(B6):9885-9907, DOI 10.1029/93JB00191

Sakic P, Piété H, Ballu V, Royer JY, Kopp H, Lange D, Petersen F, Özeren MS, Ergintav S, Geli L, Henry P, Deschamps A (2016) No significant steady state surface creep along the North Anatolian Fault offshore Istanbul: Results of 6 months of seafloor acoustic ranging. Geophysical Research Letters 43(13):6817-6825, DOI 10.1002/2016GL069600, URL http://doi.wiley.com/10.1002/2016GL069600

Schmittbuhl J, Karabulut H, Lengliné O, Bouchon M (2016) Seismicity distribution and locking depth along the Main Marmara Fault, Turkey. Geochemistry, Geophysics, Geosystems 17(3):954-965, DOI 10.1002/2015GC006120, URL http://doi.wiley.com/10.1002/2015GC006120

Seeber L, Cormier MH, McHugh C, Emre O, Polonia A, Sorlien C (2006) Rapid subsidence and sedimentation from oblique slip near a bend on the North Anatolian transform fault in the Marmara Sea, Turkey. Geology 34(February 2009):933936, DOI 10.1130/G22520A.1

Şengör A, Tüysüz $O$, İmren $C$, Sakınç $M$, Eyidoğan $H$, Görür N, Le Pichon X, Rangin C (2005) The North Anatolian Fault: a new look. Annual Review of Earth and Planetary Sciences 33(1):37-112, DOI 10.1146/annurev.earth.32.101802.120415, URL http://www.annualreviews.org/doi/10.1146/annurev.earth.32.101802.120415

Şengör AMC, Grall C, Imren C, Pichon XL, Görür N, Henry P, Karabulut H, Siyako M (2014) The geometry of the North Anatolian transform fault in the Sea of Marmara and its temporal evolution : implications for the development of intracontinental transform faults 1. Can J Earth Sci 242(February):222-242, DOI $10.1139 /$ cjes-2013-0160 
Sözbilir H, Sümer Ö, Uzel B, Softa M, Tepe Ç, Eski S, Özkaymak Ç, Baba A (2017) Ocak-28 şubat 2017 çanakkale-ayvacık depremleri ve bölgenin depremselligi. Dokuz Eylül Üniversitesi Deprem Araştırma ve Uygulama Merkezi Diri Fay Araştırma Grubu, Afyon Kocatepe Universitesi Deprem Uygulama ve Araştırma Merkezi, Izmir Yuksek Teknoloji Enstitusu Jeotermal Enerji Arastirma ve Uygulama Merkezi

Uchida N, Kalafat D, Pinar A, Yamamoto Y (2019) Repeating earthquakes and interplate coupling along the western part of the North Anatolian Fault. Tectonophysics 769:228185, DOI 10.1016/j.tecto.2019.228185, URL https://doi.org/10.1016/j.tecto.2019.228185 https://linkinghub.elsevier.com/retrieve/pii/S0040195119302926

Vardar D, Öztürk K, Yaltırak C, Alpar B, Tur H (2014) Late Pleistocene-Holocene evolution of the southern Marmara shelf and sub-basins: middle strand of the North Anatolian fault, southern Marmara Sea, Turkey. Marine Geophysical Research 35(1):69-85, DOI 10.1007/s11001-013-9210-8, URL https://doi.org/10.1007/s11001-013-9210-8

Wessel P, Luis JF, Uieda L, Scharroo R, Wobbe F, Smith WH, Tian D (2019) The Generic Mapping Tools Version 6. Geochemistry, Geophysics, Geosystems 20(11):5556-5564, DOI 10.1029/2019GC008515

Wollin C, Bohnhoff M, Martínez-Garzón P, Küperkoch L, Raub C (2018) A unified earthquake catalogue for the Sea of Marmara Region, Turkey, based on automatized phase picking and travel-time inversion: Seismotectonic implications. Tectonophysics 747-748:416-444, DOI 10.1016/j.tecto.2018.05.020, URL http://www.sciencedirect.com/science/article/pii/S004019511830204X http://linkinghub.elsevier.com/retrieve/pii/S004019511830204X https://linkinghub.elsevier.com/retrieve/pii/S004019511830204X

Yaltirak C, Sakinç M, Aksu AE, Hiscott RN, Galleb B, Ulgen UB (2002) Late Pleistocene uplift history along the southwestern Marmara Sea determined from raised coastal deposits and global sea-level variations. Marine Geology 190(12):283-305, DOI 10.1016/S0025-3227(02)00351-1

Yaltırak C, İşler E, Aksu A, Hiscott R (2012) Evolution of the Bababurnu Basin and shelf of the Biga Peninsula: Western extension of the middle strand of the North Anatolian Fault Zone, Northeast Aegean Sea, Turkey. Journal of Asian Earth Sciences 57:103-119, DOI 10.1016/j.jseaes.2012.06.016, URL https://linkinghub.elsevier.com/retrieve/pii/S1367912012002891

Yamamoto R, Kido M, Ohta Y, Takahashi N, Yamamoto Y, Pinar A, Kalafat D, Özener H, Kaneda Y (2019) Seafloor Geodesy Revealed Partial Creep of the North Anatolian Fault Submerged in the Sea of Marmara. Geophysical Research Letters 46(3):1268-1275, DOI 10.1029/2018GL080984

Zabc1 C (2019) Spatio-temporal behaviour of continental transform faults: implications from the late Quaternary slip history of the North Anatolian Fault, Turkey. Canadian Journal of Earth Sciences 56(11):1218-1238, DOI 10.1139/cjes-20180308, URL http://www.nrcresearchpress.com/doi/10.1139/cjes-2018-0308 